تغييرات زمانى دبى جريان و هدررفت عناصر غذايى، مطالعه موردى:

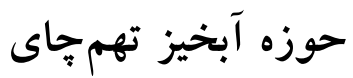

\author{
عليرضا واعظى " و يونس مظلوم على آبادى'

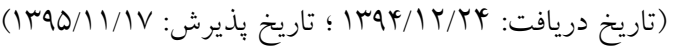

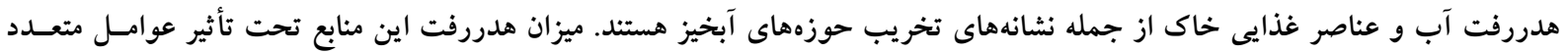

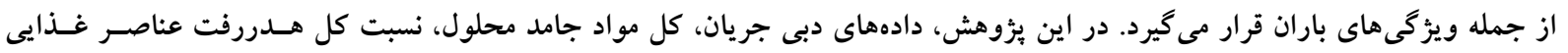

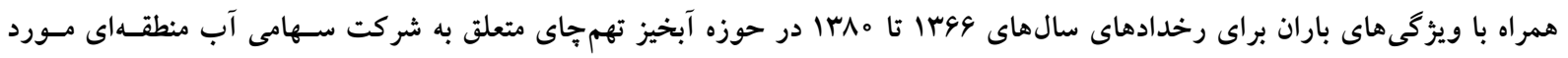

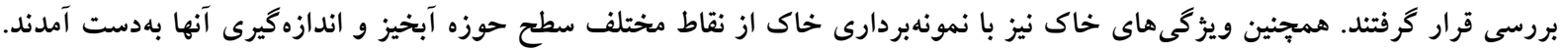

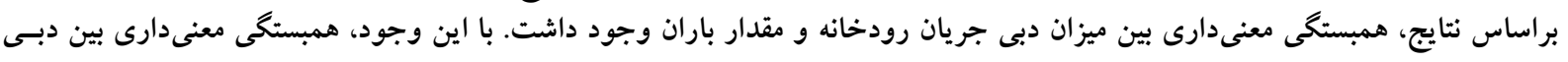

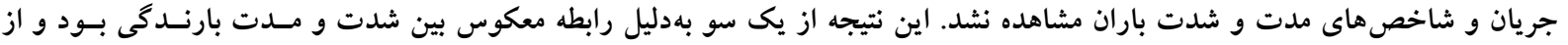

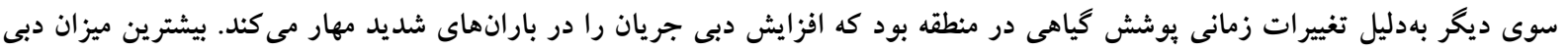

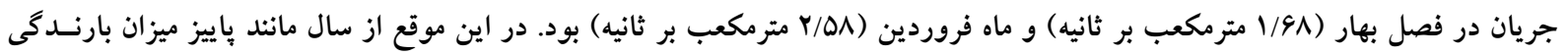

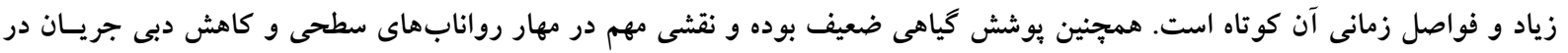

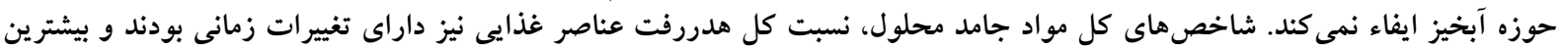

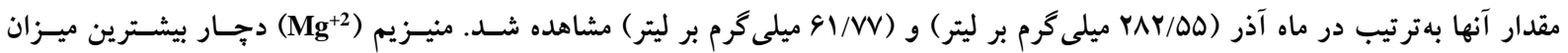

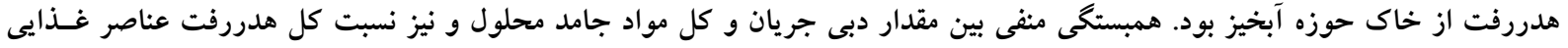

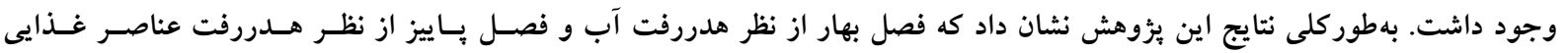

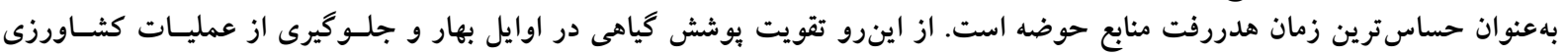

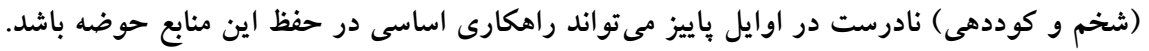

وازههاى كليدى: سلامت آبخيز، مواد جامد محلول، ويزگى هاى باران، هدررفت كيفى خاك 
با مطالعه برروى عوامل تأثير كذار بر فرسايش آبى خاك مى توان

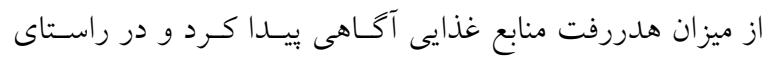

$$
\text { كاهش هدررفت آنها برنامهريزى نمود. }
$$

هدررفت عناصر غذايى از خاك توسط رواناب به دو صورت مدرد

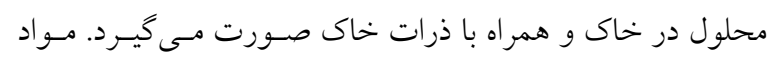

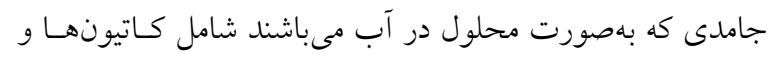

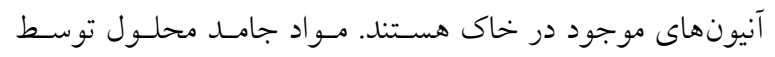

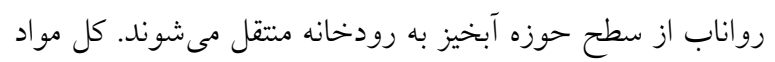

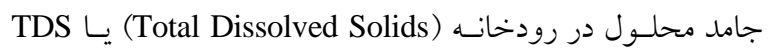

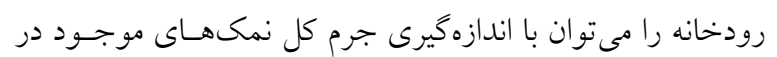

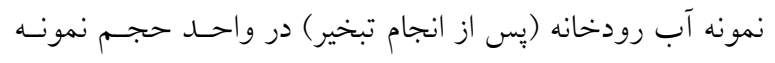

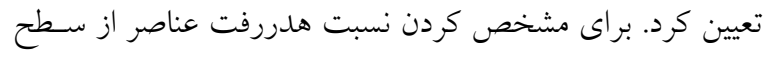

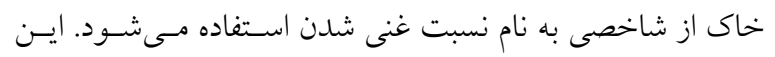

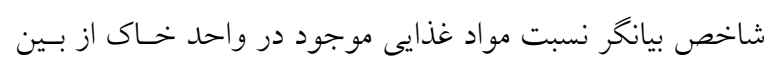

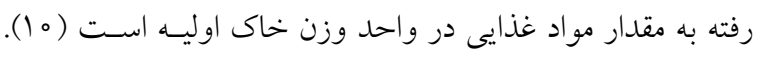
هدررفت عناصر غذايى خاى تحـت تـأثير عـواملى متعـدد قـرار

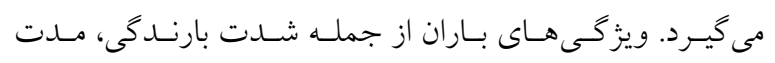

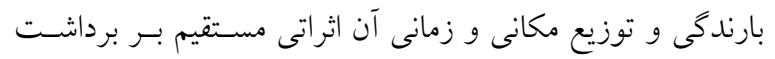

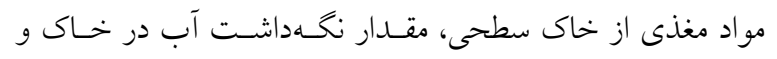
توليد رواناب سطحى دارد (19).

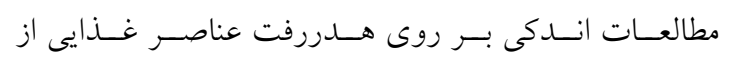

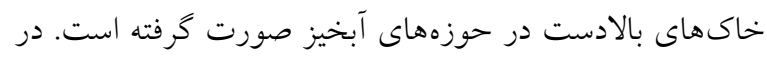

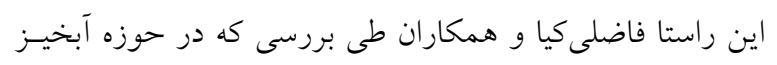

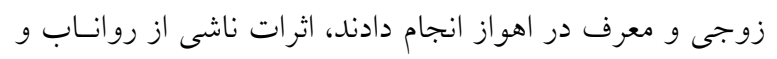

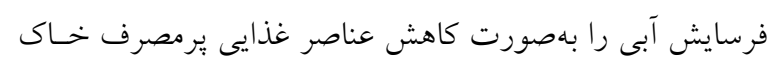

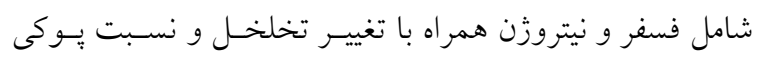

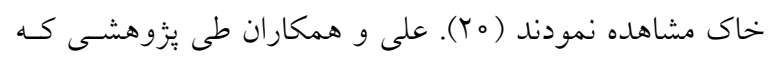

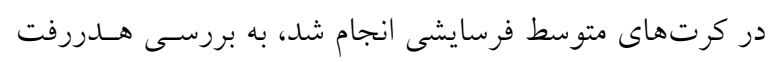

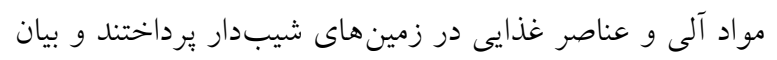

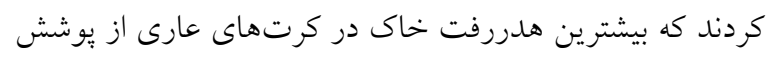

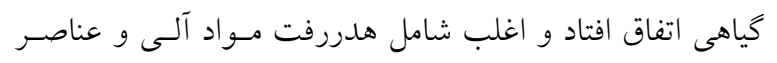

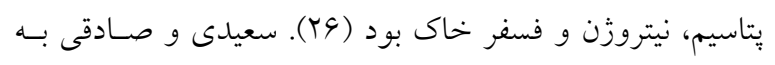

مقدمه خاك يكى از با ارزشترين منابع ملى هر كشور است. فرسـايش

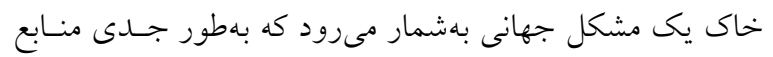

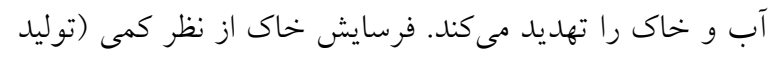
رسوب) و كيفى (هدررفت عناصر غذايى) در حوزههاى آبخيـز

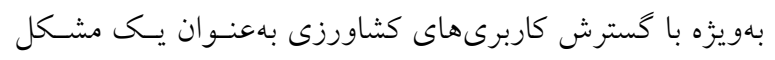

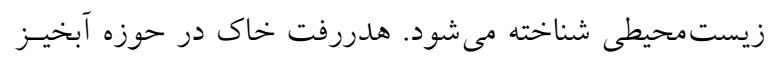

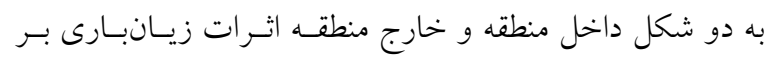

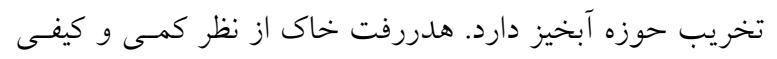

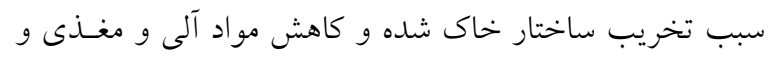

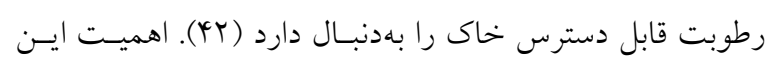

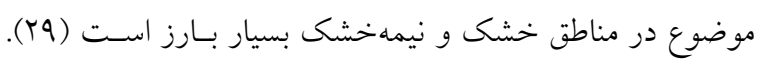
فرسايش خاك و از دست دادن مواد مغذى دو جنبه مهم و مؤثر بر توليــ محصـول و كيفيـت آب در حسوزه آبخيـز مسى باشــند.

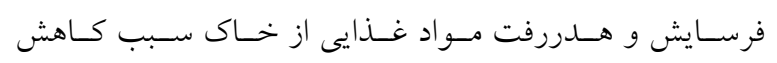

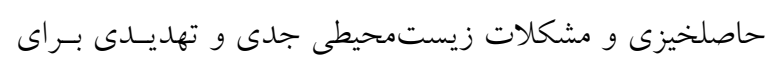

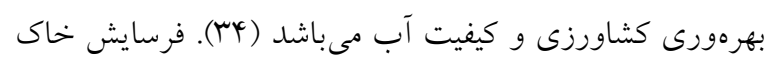

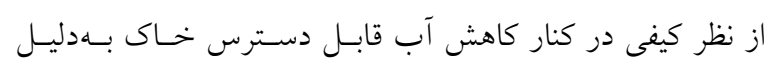

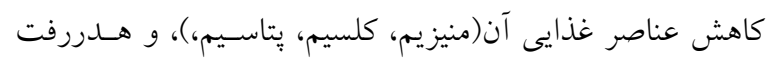

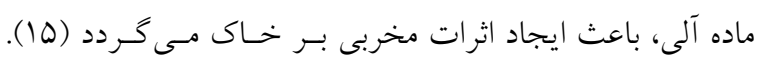

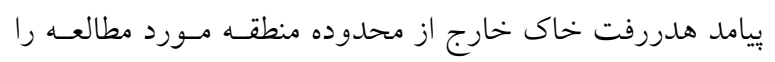

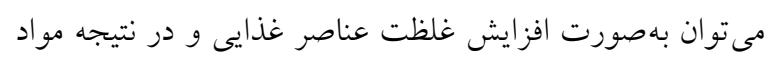

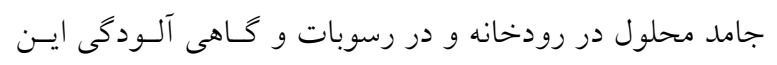

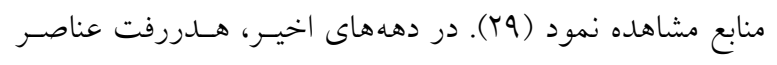

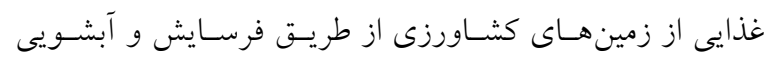

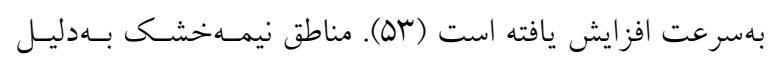

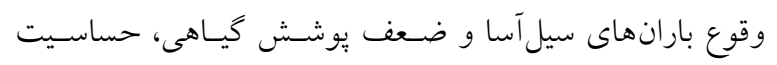
زيادى براى توليد رواناب سطحى و هدررفت خاى دارند (هارّ).

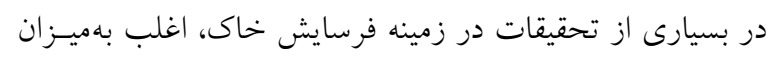

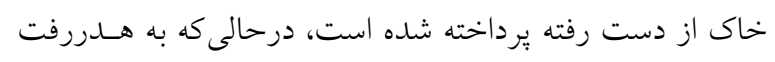

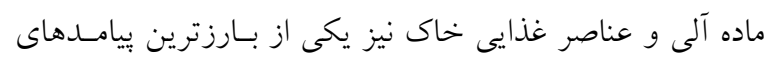

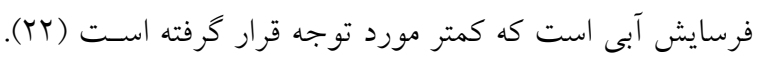


جريان و هدررفت مواد غـذايى در ابعـاد حـوزه آبخيـزدر منطقـهـ نيمهخشى در شمال غرب ايران انجام كرفت.

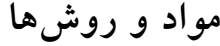 منطقه مورد مطالعه}

اين مطالعه در محدوده حوزه آبخيز تهمج جـاى در ه ا كيلـومترى

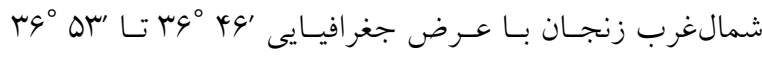

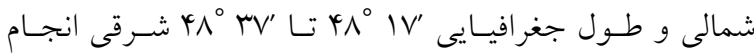
كرفت (شكل I). مساحت اين حوضه YMN19 هكتار و متوسط

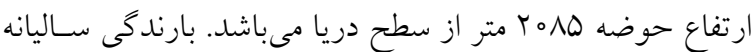

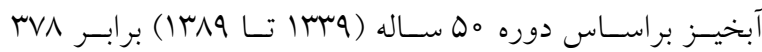
ميلى متر و متوسط دماى حوضه ه ا درجه سانتى گراد مسىباشـد.

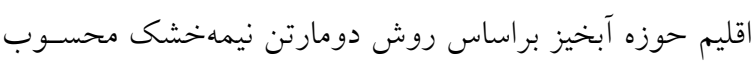
مى شود (UD). اين منطقه از نظر زمينشناسى بيشتر از تشكيلات

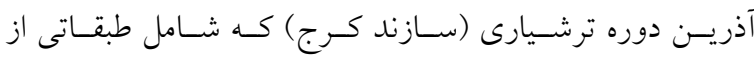
توفهاى مختلف، شيل، ماسه سنخ، سنخهاى رسى- شـيلى و تودهاى نقوذى از جنس كرانيـت و آنـدزيت هسـتند، تشـكيل شــده اســت (19). ســطح بوشــش كيــاهى مرتعـى حوضــه

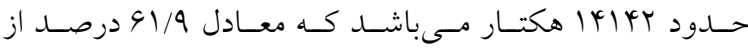
سطح كل حوضه را در بركرفته است (شـكل r). از گونـهـــاى

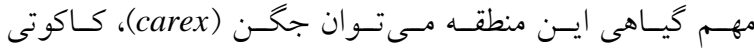

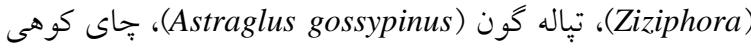
(Descurainia sophia) (ploratum Hypericum) كلايل (Gladiolus murielae)، ورى (Rosa persica)، خارشتر

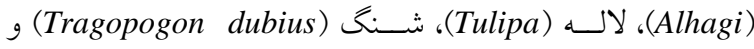
استييا (Stipa) را نام برد. اراضى ديم رها شده و يا كم بازده كـه قسمت عمده فرسايش را به خود اختصاص مى دهد با مسـاحتى سكي

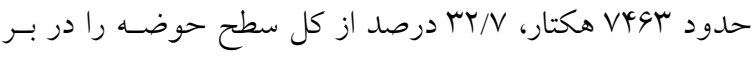
مى گيرد. ساير بخش ها حوضه نيز در حاشيه شـاخههـاى اصـلى رودخانهها بهصورت باغ و يا كشت آبى قرار دارند. خـاكهـاى منطقه در دو رده غالب اينسيتى سول (Inceptisols) و انتى سـول

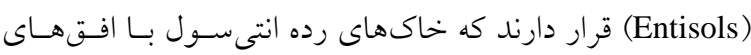

بررسى ارتباط دبى رودخانه و مـاده آلى موجـود در رسـوبات حوزه آبخيز كجور برداختند و نشان دادند كه ارتبـاط مسـتقيمى بين هدررفت ماده آلى و تغييـرات دبسى وجــود نداشـت (10). خزايى و همكاران به بررسى تخريب جنگل بر هدررفت عناصر غذايى و خاى در حوزه آخيز كجور برداختند. به همين منظـور ز كرتهاى فرسايشى در دو منطقه بكر و تخريب شده استفاده شد. نتايج نشان داد كه بيشترين هدررفت مربوط به مواد آلى و كمترين هدررفت مربوط به فسفر خاك بود (V). نيو و همكاران به بررسى ميزان فرسايش و هدررفت عناصر غذايى (كربن كـل، نيتروزن كل و ماده آلى) براساس جهار نـوع كـاربرى در حـوزه

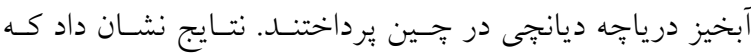
بيشترين هـدررفت عناصـر در كـاربرىهـاى كشـاورزى تحــت خاكورزى مشاهده شد (سب). اوتـرو و همكــاران در آمريكـاى جنوبى به بررسى ميزان هدررفت عناصر غذايى توسط روانـاب سطحى در دو كاربرى كشاورزى (با الخوى كشت سيبزمينسى) و مرتع (مختص جراى دام) پيرداختنـد. نتـايج نشـان داد كـه در زمينهاى تحت كشت سيب زمينى بهدليل دخالتهاى انسـانى، هلدرفت كمى خاك و كيفى خاك از جمله ازت و فسفر بيشـتر از كاربرى مرتع بود (Y) (Y). اخر جهه مطالعات زيادى در مورد هــررفت عناصـر غـذايى از خاى در ابعاد كرت تحت بارانهاى شـبيهسـازى شــده (r و و اV، IV، ليكن مطالعهاى دقيق در مورد هدررفت مواد غـذايى از خـاك در ابعاد حوزه آبخيز انجـام نخرفتـه اسـتـ اغلـب مطالعـاتى كـه در رودخانه هاى حوزههاى آبخيز انجام گرفته است، به بررسى مقدار دبى و بارمعلق يا هدررفت مواد آلى خاك متمركز گرديدهاند

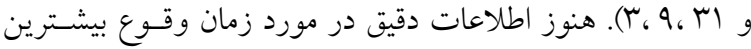
هـــررفت مــواد غــذايى از حــوزههــاى آبخيـز و ارتبــاط آن بــا مشخصـات هيـدرولوزيكى آبخيـز (دبسى جريـان رودخانسه) و ويزگیى هاى باران وجود ندارد. با توجه به اهميتسى كـه هـدررفت مواد غذايى از خاى بـهنصـوص در حــوزههــاى آبخيـز منـاطق نيمهخشى دارد، اين يزّوهش بهمنظور بررسى تغييرات زمانى دبى 
نشريه علوم آب و خاك (علوم و فنون كشاورزى و منابع طبيعى) / سال بيست و دو / شماره يك/ بهار IrqV
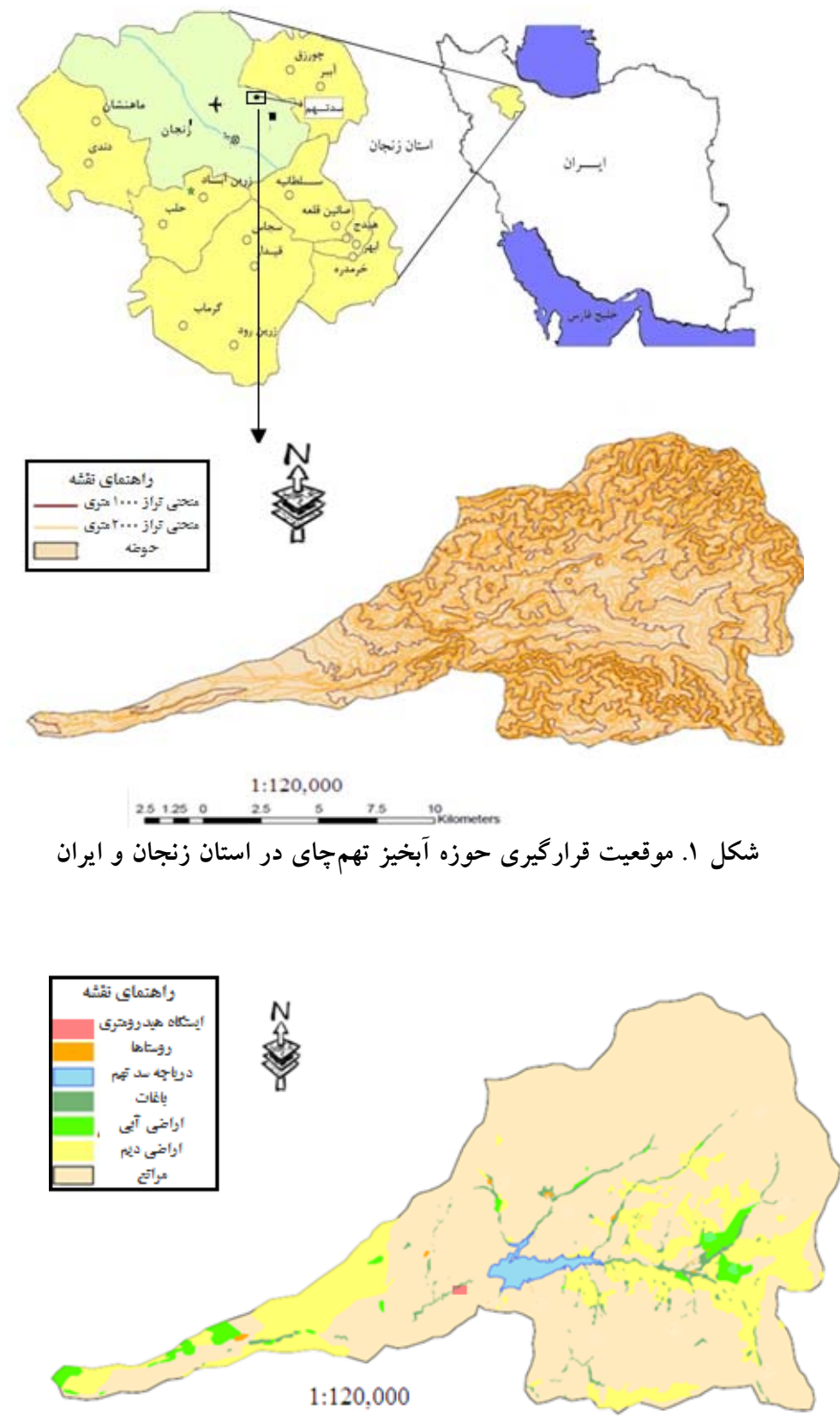

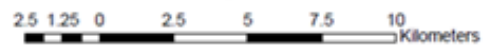

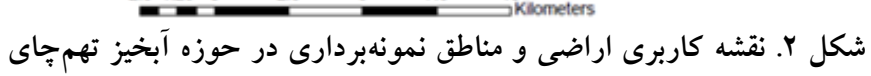

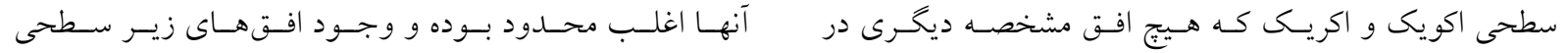

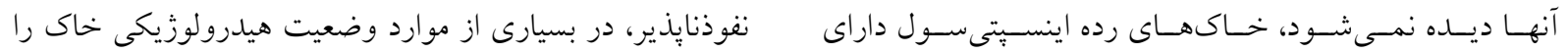

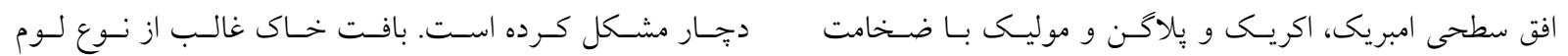

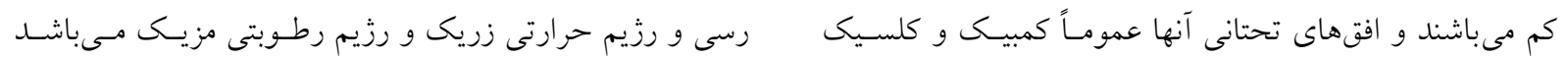
و كاهى جيبسيك و يا يتروجييسيك مى باشند. تكامل نسيمرخسى (19). 
سرشاخهها انتخاب شدند. در هر مكان در امتداد هـر سرشـاخه،

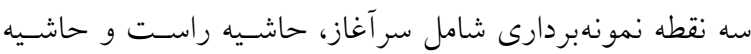

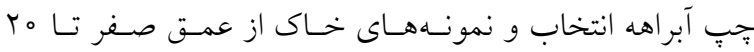

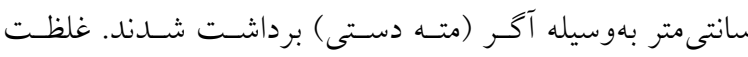
عناصر كلسيم (

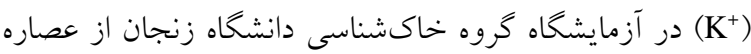
كل اشباع خاكهاى نمونهبردارى و بهوسيله دستخاه فليم فتومتر

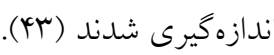

\section{اندازهيرى ويزگ مهاى باران}

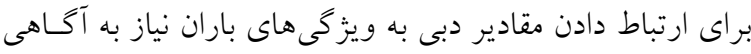

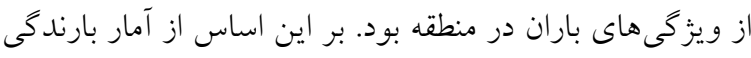

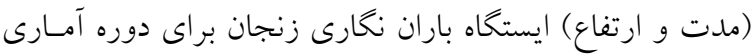

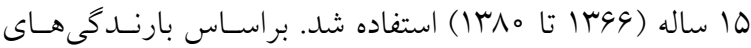

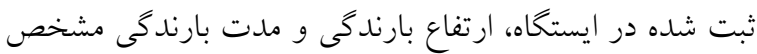
شد. شدت باران براساس نسبت مقدار بارندگى بـهمـــت بـاران

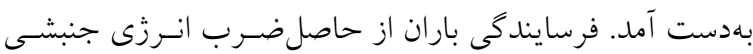

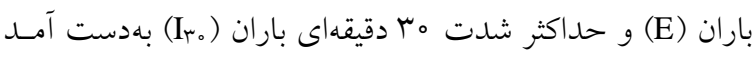

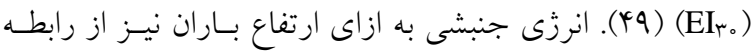

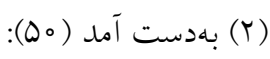

$\mathrm{KE}=11 / \wedge \vee+\wedge / \wedge^{\mu} \log \mathrm{I}$

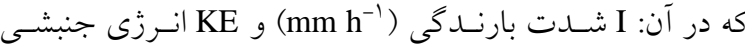

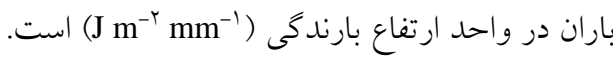

\section{تجزيه و تحليل دادهها}

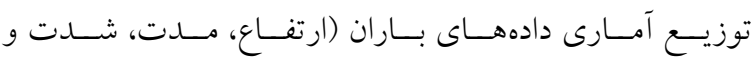

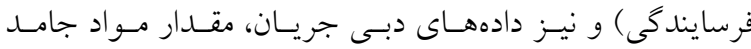

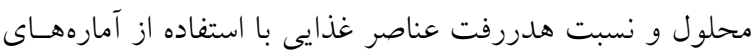
جولكى و كشيدگى مورد ارزيابى قرار گرفتند. تغييـرات زمـانى

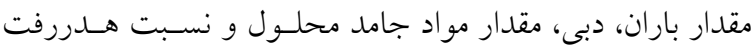
عناصر غذايى در ابعاد زمانى (فصلى و ماهانسه) براسـاس روش تجزيه واريانس با استفاده از آزمون تـوكى مـورد مقايسـهـ قـرار
اندازهگيرى دبى رودخانه، مقدار مواد جامد محلول و نسـبت هدرفت عناصر غذايى خاك براى بررسى دبى رودخانه تهم:جاى و ميزان مواد جامد محلـول از

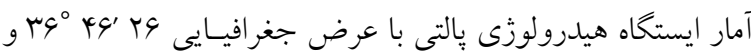

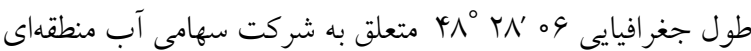

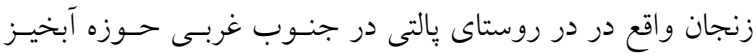
استفاده شد. دبى جريان رودخانه توسط اشل قرائت عمـق جريـان دو بار در روز و براى تعيين مقدار كل مواد جامد محلـول (TDS)،

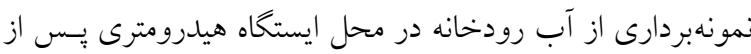

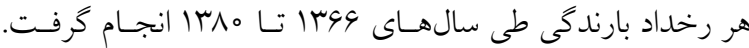

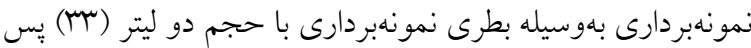
از هر بارش انجام كرفت. نمونههاى برداشت شــده بـهـ آزمايشـاه برده شده و يّ از صاف كردن با كاغذ صافى، محلـول در آون بـا دماى هـ ا درجه سانتى گراد خشى گرديد. غلظت عناصر كلسـيم و منيزيم $\left(\mathrm{Ca}^{+r}\right)$

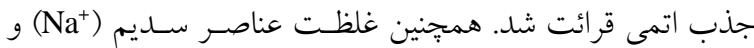

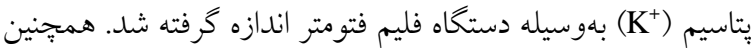

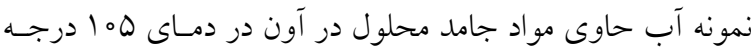

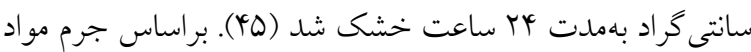

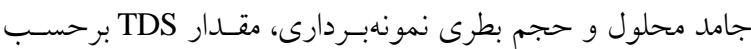
ميلى گرم در ليتر مشخص شد. همجنسين مقــادير pH و EC نمونـهـ آب بهعنوان معيارهاى مهم ارزيابى كيفيت شيميايى آب رودخانسه،

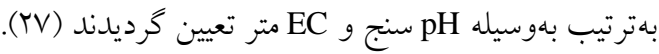

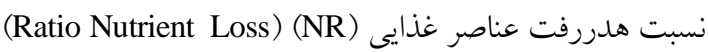

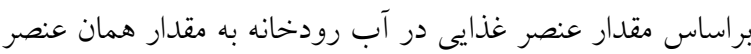

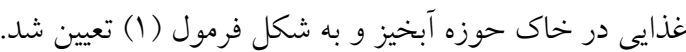

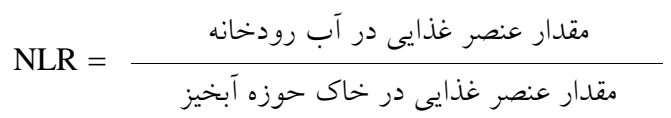

هدف از ارائه اين نسبت، امكان ايجاد مقايسه بين عناصر غذايى مختلف خاك از نظر ميزان هدررفت در جريـان رودخانـه بـود. براى تعيين مقدار عناصر غذايى خاك، نمونهبردارى از مب مكان

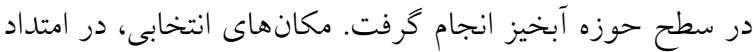


نشريه علوم آب و خاك (علوم و فنون كشاورزى و منابع طبيعى) / سال بيست و دو / شماره يك/ بهار IrqV

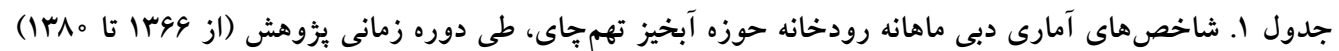

\begin{tabular}{|c|c|c|c|c|c|c|c|c|c|}
\hline \multicolumn{4}{|c|}{ دبى جريان رودخانه (مترمكعب بر ثانيه) } & \multicolumn{4}{|c|}{ ارتفاع باران (ميلى متر) } & \multirow{2}{*}{ رخداد } & \multirow[t]{2}{*}{ ماه } \\
\hline دامنه & انحراف & 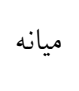 & ميانخين & 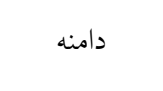 & انحرياف & ميانه & ميانخين & & \\
\hline$\Delta / r_{-} \circ / \mathbb{R}$ & $\circ / 4$ & $T / 9 \mu$ & $r / \Delta \wedge$ & $r G / V Y-1 / 0 T$ & $1 / \uparrow \wedge$ & r/AYI & $\Delta / \wedge \circ$ & 11 & فروردين \\
\hline $0 / \mu V-0 / N$ & $0 /$ HY & $T / T Q$ & r/or & $r 1 / 90-1 / 09$ & $1 / 01$ & r/A & $Y / 94$ & ro & ارديبهشت \\
\hline $1 / 1 V-0 / 0 V$ & $0 / 19$ & $\circ / \Upsilon_{0}$ & $\circ / 44$ & $10 / 91-1 / 0 r$ & l/AV & $r / \Delta Q$ & $0 / 09$ & $\wedge$ & خرداد \\
\hline$Y / r 1-0$ &.$/ 9 \Lambda$ & $\circ / 10$ & $\circ / \mathrm{V} \wedge$ & $|V / \cdot 0-1 / 0|$ & $r / Y_{0}$ & r/AY & $0 / 11$ & 0 & تير \\
\hline$\circ / T V-\circ$ & $\circ / \circ 4$ & $\circ / 10$ & $\circ / 11$ & $r / 0 r-1 / 0 r$ &.$/ 19$ & $1 / \wedge V$ & $1 / 04$ & r & مرداد \\
\hline $0 / 0 Y-0 / 01$ & $0 / 01$ & O०Y & $0 / 01$ & $\mid Y / Y Y-1 / 19$ & $r / 9 \Lambda$ & $11 / 0 r$ & $N / 9 V$ & r & شهريور \\
\hline $1 / M-^{-0}$ & $0 / 1 r$ & $\%$ & $0 / T \Delta$ & $1 \% / r \Delta-1 / 00$ & $1 / 09$ & $r / Y \wedge$ & $Y / \circ Y$ & Ir & مهر \\
\hline$T / Q T_{-}-0$ &.$/ 11$ &.$/ 11$ & $0 / Y \Lambda$ & $r / r /-0 / V T$ & $1 / 1 T$ & $4 / 4 q$ & $0 / 9 T$ & Tr & آبان \\
\hline$\circ / r \Delta-\circ / \circ \wedge$ & O/TY & $\circ / \Lambda$ & $\circ / 1 \wedge$ & $19 / 4 T-0 / 94$ & $1 / 09$ & $1 / 11$ & $4 / 99$ & ir & آذ آذر \\
\hline & $0 \%$ & $0 / 19$ & $0 / 19$ & $D / r G-1 / \Delta T$ & $\circ / 4 V$ & $r / 9 \circ$ & $r / 0 r$ & V & دى \\
\hline$\circ / V \mu-0 / Y r$ & $0 / 19$ & $0 / K Y$ & $\circ / 4$ & $V / \Psi \backslash-Y / Q V$ & $1 / 40$ & $\mathrm{r} / \mathrm{VV}$ & $\varphi / D \Lambda$ & r & بهمن \\
\hline$r / 90-0 / / r$ & $\circ / T V$ & $\circ / \Delta \Lambda$ & $\circ / 9 V$ & $q / 0 q-1 / 4 \wedge$ & O/MG & $r / 90$ & $\mu / \circ \Lambda$ & Ir & اسفند \\
\hline
\end{tabular}

جريان در ماههاى مختلف طى دوره آمارى بزّوهش نشان داد كـه. در مقياس ماهانه تفاوتى معنسى ار از نظـر دبسى جريـان رودخانـه (P<0/001) وجود داشت (جدول Y). ميزان جريـان در رودخانـه طى سال به عوامل متعددى از جمله ويزگكى هـاى بـاران (مقــار،

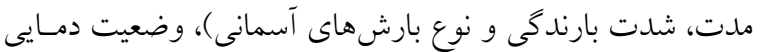

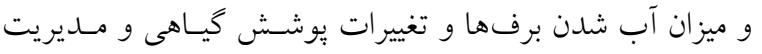

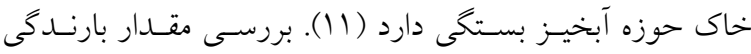
فصلى و ماهانه در دوره آمارى 10 سـاله نشـان داد كـه بيشـترين

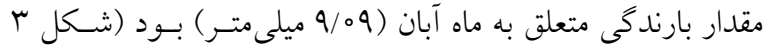

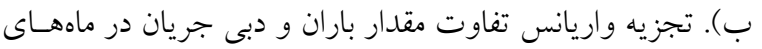

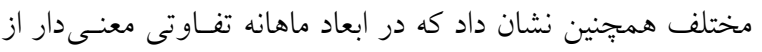
نظر مقدار باران (P>0/0) وجود داشت (جدول r).

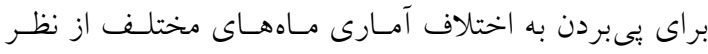

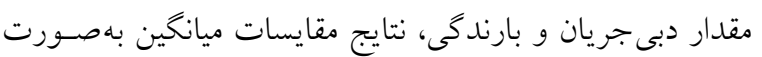

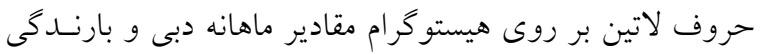

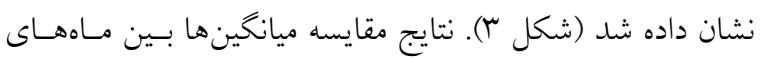
سال از نظر مقدار دبى جريان رودخانه نشان داد كه ماه فروردين

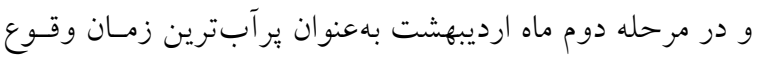

كُفتند. رابطه بين دبى و ويزَگى هاى باران بـا استففاده از توابـع

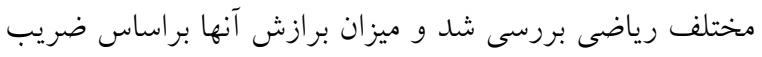

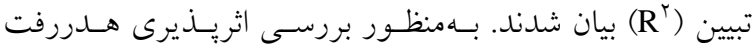

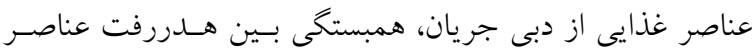

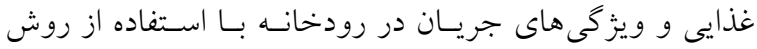

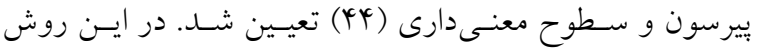

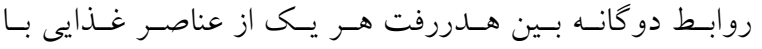

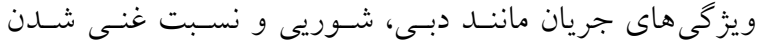
بلصورت خطى محاسبه و براساس ضريب همبسـتخى (r) بيـان

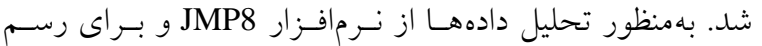
نمودارها از نرم|فزارهاى Excel2013 استفاده شد.

\section{نتايج و بحث} تغييرات زمانى دبى جريان بررسى تغييرات زمانى دبى جريان رودخانه در حوضه براسـاس

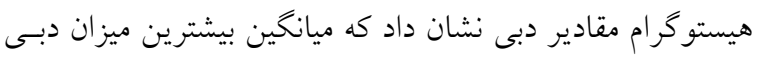

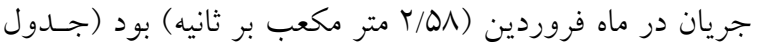

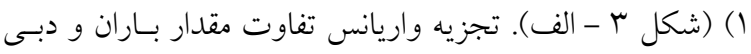



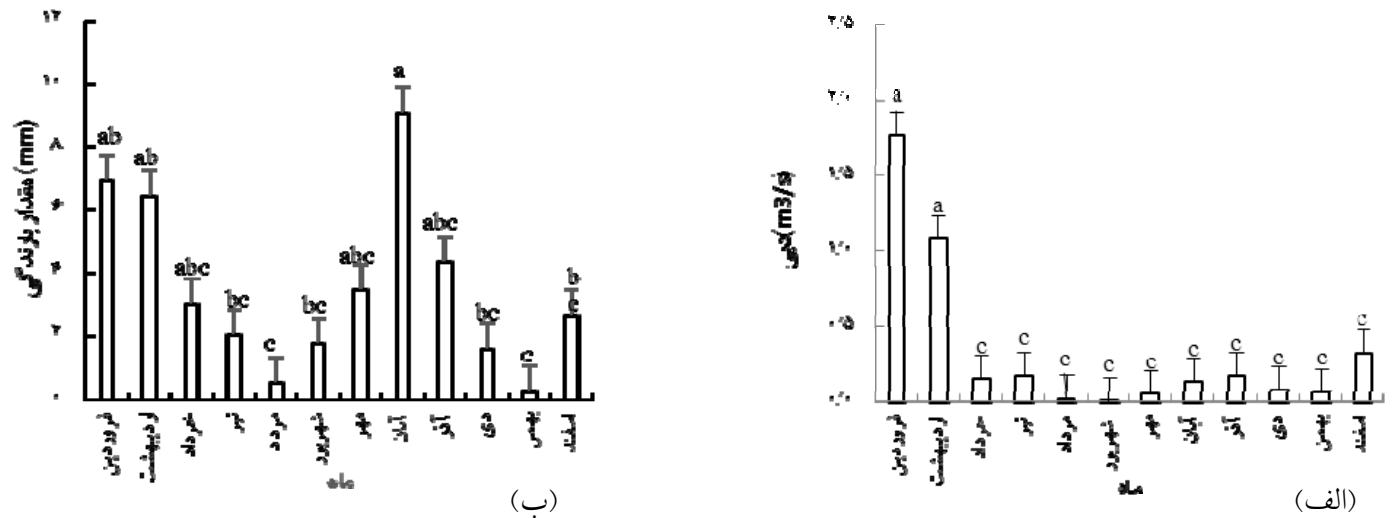

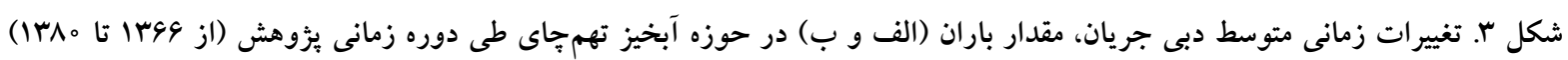
حروف انخليسى متفاوت بيانگر وجود تفاوت معنىدار در بين ماهها است

جدول r. تجزيه واريانس تغييرات مقدار دبى جريان رودخانه و باران در ابعاد ماهانه در حوزه آبخيز تهمجاى،

\begin{tabular}{|c|c|c|c|c|c|}
\hline سطح معنى دارى & $\mathrm{F}$ & ميانخين مربعات & درجه آزادى & مجموع مربعات & متغيير \\
\hline$<\circ / \circ \circ \circ$ & $\Lambda / Y I$ & $r / 99$ & 11 & $\mathrm{FT/AV}$ & دبى جريان رودخانه \\
\hline$<0 / 009$ & $r / 4 q$ & $104 / 00$ & 11 & $110 \% / 10$ & مقدار باران \\
\hline
\end{tabular}

بهدليل وجود رابطه عكس بين شـدت و مـدت بارنـدكىهـا در حوزه آبخيز باشد (شكل ه). در واقع بيشتر رخدادهاى باران كه

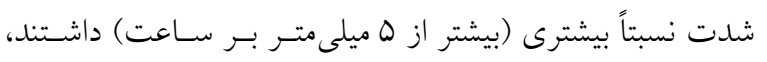
بهدليل كوتاه بودن تداوم بارش (كمتـر از يـك سـاعت) مقـدار رواناب كمتر داشته و در نتيجه دبى جريان رودخانه يايينترى را موجب شدند. در رخدادهايى از باران نيز كه تداوم نسـبتاً كمسى داشتند (بيشتر از يك ساعت) بهدليل بـايين بـودن شـدت آنهـا

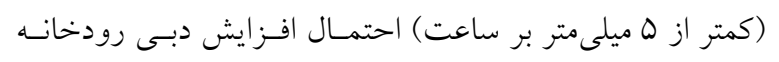
يايين بود (م ا). از سوى ديخر وجــود تغييـرات زمـانى از نظـر درصد يوشش گياهى و نيز انجام عمليات خاكورزى (شخم و كشت) به نوبه خود موجب مى گردد در برخى بارانهاى شـديد بهدليل وجود يوشش كياهى مناسـب، يـا عـدم وجــود شـخم و كشت، توليد رواناب سـطحى، دبسى جريـان رودخانسه افـزايش جندانى بيدا نكند. وجود رابطه مثبت و معنى دار بين دبسى جريسان رودخانسه و
جريان رودخانه، تفاوتى قابل ملاحظه بـا سـاير مـاههـاى سـال دارند. اين نتايج مسى توانــد مؤيسـا بيشـترين فرسـايش خـاى در

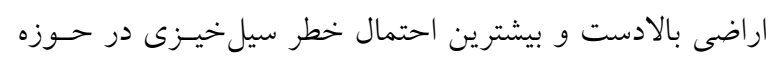
آبخيز در اين موقع از سال باشد.

رابطه بين خصوصيات جريان سطحى و ويز گیىهاى باران بررسى رابطه بين دبى جريان با ويز گیىهاى باران (ارتفاع، مدت، شدت و فرسايندگى) براى وسا رخداد بررسى شده باران- دبى

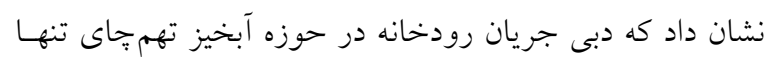

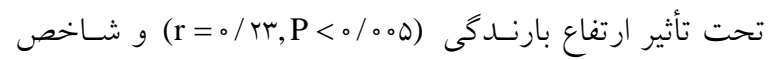

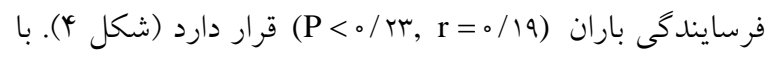

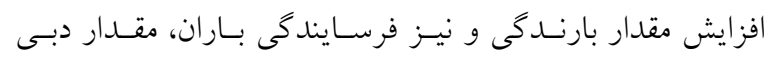
جريان رودخانه بهطور قابل توجهى افزايش يافت. با اين وجـود

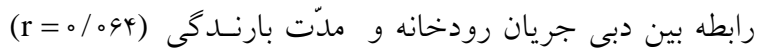

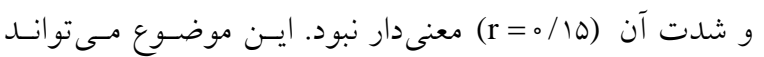


نشر يه علوم آب و خاك (علوم و فنون كشاورزى و منابع طبيعى) / سال بيست و دو / شماره يك/ بهار IrqV
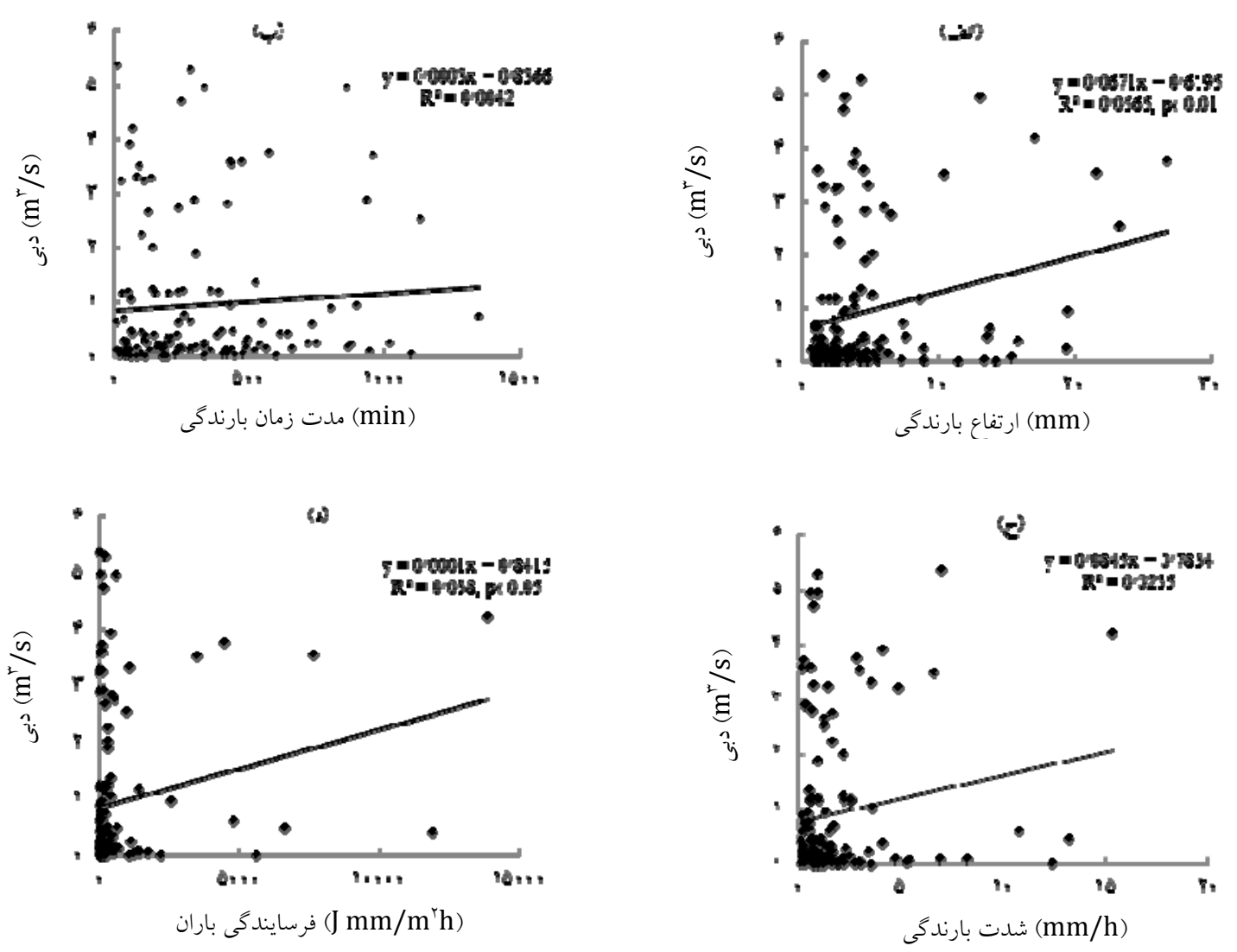

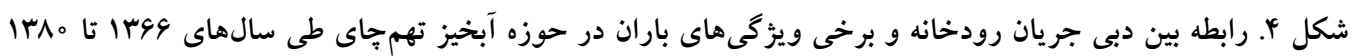

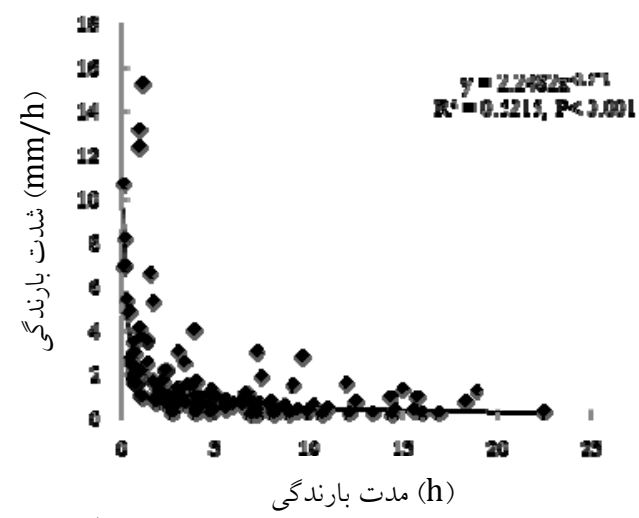

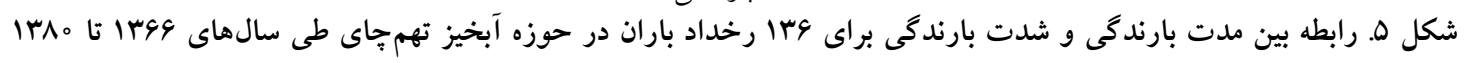

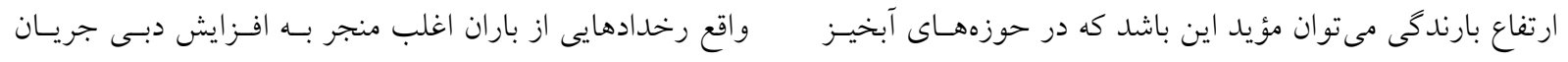

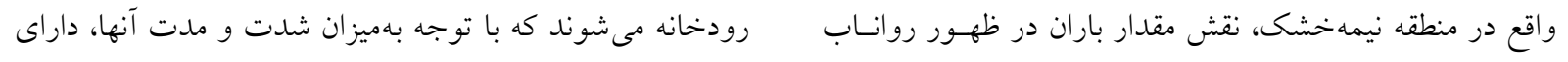

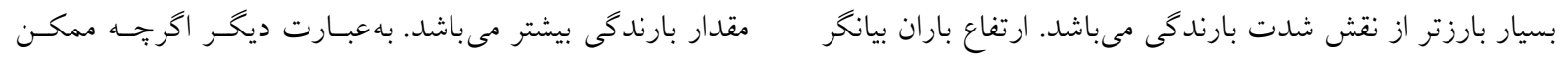

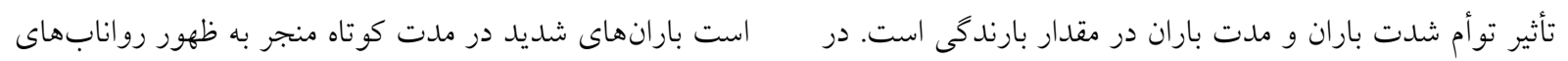



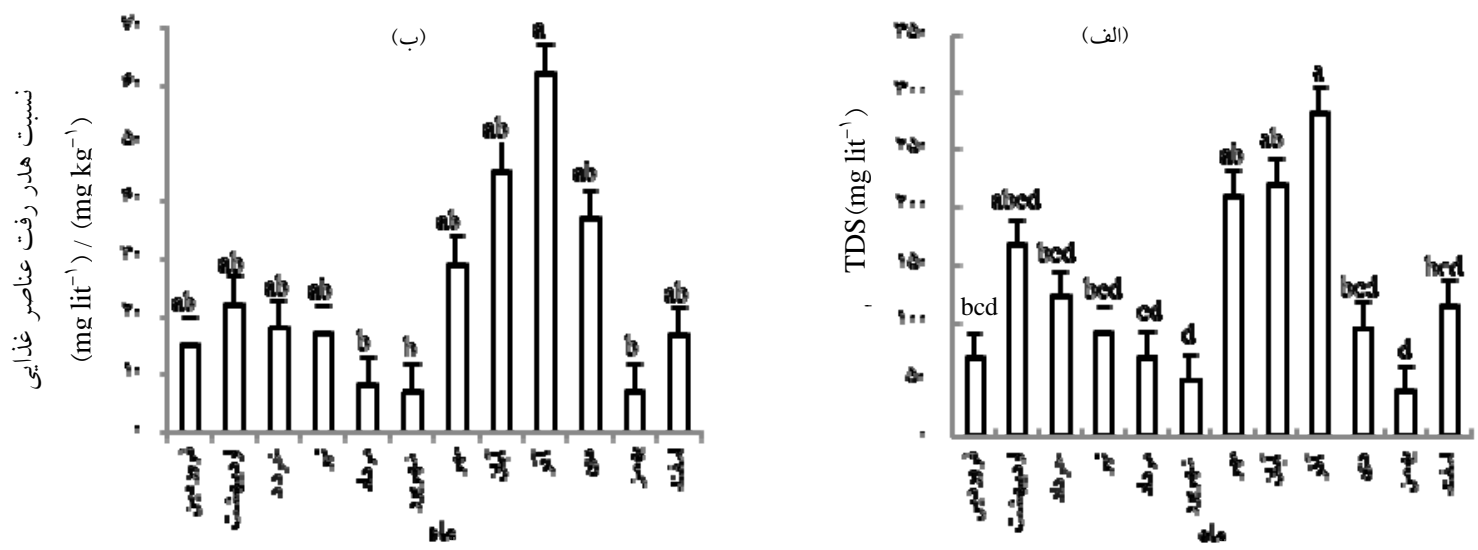

شكل צ. الف) تغييرات زمانى مقدار مواد جامد محلول و ب) نسبت هدررفت عناصر غذايى در حوزه آبخيز تهمجاى طى

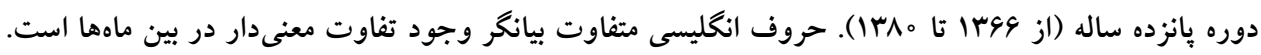

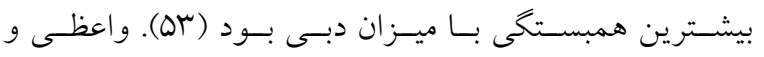
همكاران (INVV) به ارزيـابى شـاخص هـاى فرسـايند

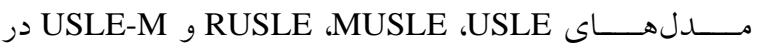
خاك هـاى نيمـهـخشـى هشـترود اسـتان آذربايجــان شـرقى يرداختند و بيان كردند كه شاخص فرسايندكى باران بر مبناى حســاكثر شـــت مب دقيقـهاى مناسـبـتـرين شـاخص بــراى بيشبينى هلررفت خاك در منطقه نيمهاخشك مىباشد (YY).

تغييرات زمانى مقدار مواد جامد محلـول و نسـبت هـدرفت

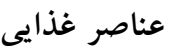
نتايج تجزيه واريانس نشان داد كه تغييرات قابـل تـوجهى از نظـر TDS

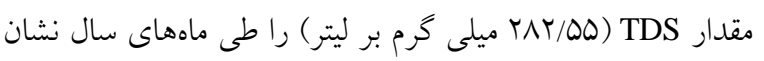
داد (شكل و الف). در اين بازه زمانى احتمـال ظهـور روانـابهــا يايين است اما هدررفت املاح خاك بسيار بـالا اسـت. در همسين

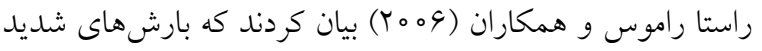
سبب به وجود آمدن رواناب بالا و رقيق شدن آب و يايين آمـدن غلظت املاح مى شود (4) (1). نتايج تجزيه واريانس همجينين نشـان داد كه تغييرات معنى دارى از نظـر نسـبت NR (ه/०)

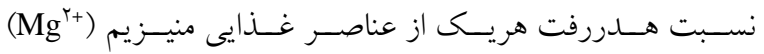

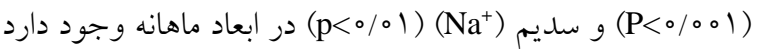

سطحى شوند ليكن اغلب اين جريانها به رودخانسه حوضسه راه بيدا نمى كنند. از اين رو احتمال وقوع دبىهاى بالا تنهـا زمـانى

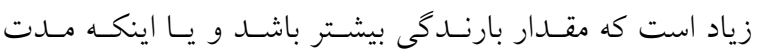
بارندكى زياد باشد كه بتوان حداكثر شدت در زمانهـاى بيشـتر حاصل شود و موجب افزايش دبى گـردد. علـت وجــود رابطـه مثبت معنى دار بين دبسى جريـان رودخانـه و فرسـايندكى بـاران نيز از آنجاست كه تنها بارانهايى كه داراى تداوم زياديى (EIro) بوده و در نتيجه شاخص حداكثر شـدت مب دقيقـهاى (Iro) در آنها قابل بيان مىباشد، منجر به توليد رواناب و افزايش دبسى جريان رودخانه مىشوند. در واقع بارانهايى كه تداوم بالايى

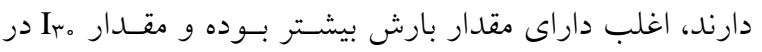
آنها قابل محاسبه است. من و همكاران بيان كردند تغييـرات

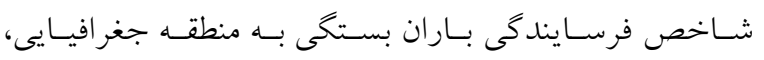
مقياس، شرايط محلى و نوع انـدازهذيـرى دارد (وس). بــهـ هـر حال در تحقيقاتى كـه در ابعـاد كوجــى (كـرت فرسايشىى) تحت باران انجام مى گيرد، امكان دستيابى به رابطه قوى بـين شاخص 。تIr و مقدار رواناب يا هلررفت خاك بسـيار زيـاد است. زانگ و همكاران بهمنظور تعيين مناسبترين شـاخص فرسايندگى باران براى وقوع رواناب و دبى جريان، ه مـدت

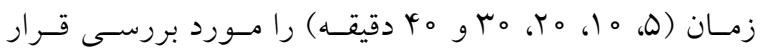
دادند و نتيجه كرفتند كه حســاكثر شـــت مب دقيقـهاى داراى 
جدول r. تجزيه واريانس تغييرات كل مواد جامد محلول و نسبت هدررفت كل عناصر غذايى، نسبت هدررفت هر يك از عناصر غذايى،

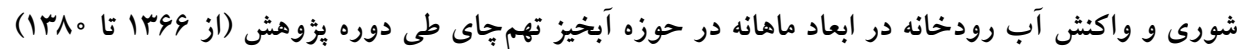

\begin{tabular}{|c|c|c|c|c|c|}
\hline سطح معنى دارى & F & ميانخين مربعات & درجه آزادى & مجموع مربعات & متغيير \\
\hline$<0 / 00 Y$ & $r / 91$ & V०ᄉrQ/99 & 11 & NDAYQY/TY & كل مواد جامد محلول \\
\hline$<0 / 011$ & $T / T, T$ & $99 \wedge 9 / T \wedge$ & 11 & $V T \Delta \wedge r / 09$ & نسبت هدرفت كل عناصر غذايى \\
\hline$<\circ / Y Y \wedge$ & $1 / Y V$ & IT\&/Ar & 11 & $\| M 90 / \circ \wedge$ & نسبت هدررفت كلسيم \\
\hline$<\circ / \circ \circ \circ$ & 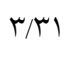 & IOSO/AT & 11 & $18199 / \circ 0$ & نسبت هدررفت منيزيم \\
\hline$<0 / 010$ & $\circ / 94$ & $0 / 01$ & 11 & $\circ / 11$ & نسبت هدررفت يتاسيم \\
\hline$<0 / 001$ & $r / 9 T$ & rIV/Q。 & 11 & $r r q r / 4 q$ & نسبت هدررفت سديم \\
\hline$<\circ / \circ \circ V$ & r & rt & 11 & rar & شورى آب \\
\hline$<0 / 0 r$ & $r / 01$ & $\| r \Delta \wedge V / \circ \Delta$ & 11 & ITHAOFV & واكنش آب \\
\hline
\end{tabular}

آب و هدررفت املاح در اختيار بخذارد. براساس نتايج، تفـاوتى دمانى معنى دار بين ماههاى مختلف سال از نظـر

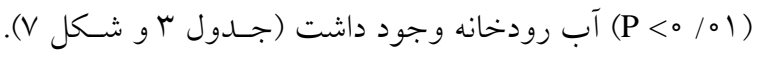
بيشترين درجه شورى و اسيديته آب رودخانه بهترتيـب در مـاه شهريور (U/D دسىزيمنس بر متر) و ماه بهمن (V/9) و كمترين

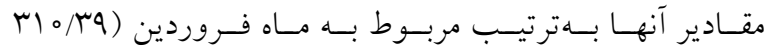
دسىزيمنس بر متر) و ماه دى (G/MV) بـود. زيـاد بـودن درجـهـ شورى خاى در ماه شهريور از يكسو بهواسطه زياد بودن ميزان عمليات خاكورزى و كشت، قابليـت انحـلال امـلاح، مصـرف كودهاى شيميايى و عدم مصرف توسـط يوشـش كيـاهى بـود. يايين بودن اسيديته در ماه بهمن را مىتوان بـه كـاهش انحسلال

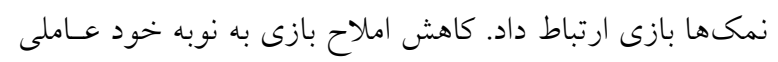

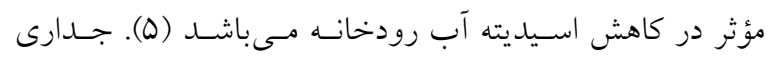
عيوضى و همكاران با بررسى عوامل مؤثر بـر كيفيـت شـيميايى

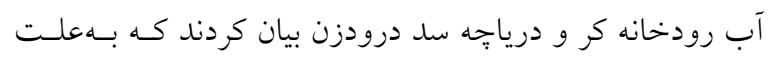
ورود رسوبات حاوى كربنات كلسيم به آب رودخانه در ماههاى

مختلف سال اسيديته بين V/T تا N/ متغير بود (ه).

وابستگى هدررفت عناصر غذايى به دبى جريان و ويز گیىهاى كيفى آب رودخانه همبستكى بين هدررفت عناصر غذايى با دبى جريان رودخانه و
(جسـول r). بيشـترين ميـزان NR در مـاه آذر (9l/VV) مشــاهده كرديد (شكل و ب). جودى و اسدى به بررسى تغييرات مكانى و زمانى برخى عناصر موجود در رودخانـه يُسـيان در حـوزه آبريـز درياى خزر يرداختند و بيان كردند بيشترين هدررفت نيتـروزن در فصل زمستان و بيشترين هلررفت مـواد آلى و فسـفر در فصـل

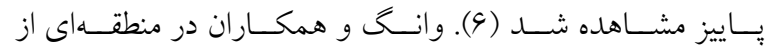
شانخهاى جين بررسىهـايى بـر روى رابطـه هـدررفت عناصـر نيتروزن و فسفر از خاى و ذخيرهسازى در درياجـهـ يـاييندسـت انجام دادند و نشان دادند كه بيشترين همبسـتخى بـين هـدررفت عناصر غذايى از خاى و ذخيرهسازى در درياجِه در فصل تابستان و كمترين همبستكى در فصل زمستان وجود داشت (†^). تغييرات زمانى درجه شورى و اسيديته آب رودخانه درجه شورى آب رودخانه (EC) از جمله شاخص هـايى اسـت كه مىتواند نشاندهنده مقدار كـل مـواد جامـــ محلـول (TDS) باشد. افزايش مواد جامد محلـول نيـز ممكـن اسـت بـهواسـه هدررفت بيشتر عناصر غذايى خـاك باشــ (أl). در كنـار ايسن شاخص، مقدار اسيديته (واكنش) زياد آب مىتواند مؤيد ميـزان حضور كاتيونهاى بازى مانند كلسيم، منيزيم، يتاسـيم و سـديم در آب رودخانسه باشـــ. از ايسـرو بررسسى شـاخص شـورى و اسيديته آب مىتواند اطلاعات ارزشمندى از نظر وضعيت كيفى 

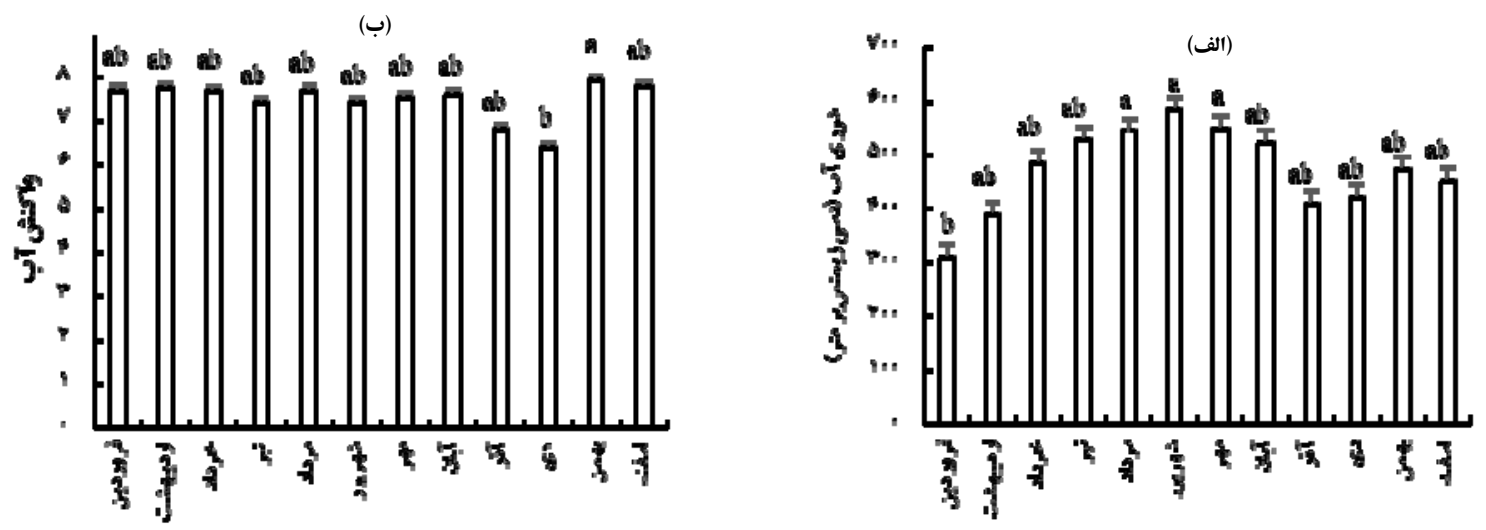

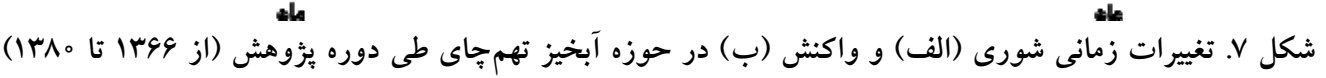

$$
\begin{aligned}
& \text { حروف انگليسى متفاوت بيانگر وجود تفاوت معنىدار در بين ماهها است }
\end{aligned}
$$

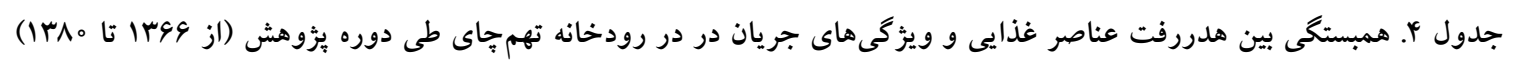

\begin{tabular}{|c|c|c|c|c|c|c|c|c|c|}
\hline $\mathrm{Q}$ & TDS & $\mathrm{pH}$ & EC & NR & $\mathrm{K}^{+}$ & $\mathrm{Na}^{+}$ & $\mathrm{Mg}^{+r}$ & $\mathrm{Ca}^{+r}$ & متغيير \\
\hline & & & & & & & & 1 & $\mathrm{Ca}^{+r}$ \\
\hline & & & & & & & 1 & $0 / 01$ & $\mathrm{Mg}^{+r}$ \\
\hline & & & & & & 1 & $0 / 9 r^{* * *}$ & $0 / 1 T$ & $\mathrm{Na}^{+}$ \\
\hline & & & & & 1 & $\circ / \Delta r^{* * *}$ & $\circ / 9 \Upsilon^{* * * *}$ & $-0 / 0 Y$ & $\mathrm{~K}^{+}$ \\
\hline & & & & 1 & $\circ / \Delta 9^{* * *}$ & $0 /\left.9\right|^{* * *}$ & $0 / 9 \mathrm{~V}^{* * *}$ & $\circ / N^{* * *}$ & NR \\
\hline & & & 1 & \%०Y & $-0 /\left\{\left.\right|^{* * *}\right.$ & & $-0 / 19^{*}$ & $\circ / \circ \mathrm{V}$ & EC \\
\hline & & 1 & $\circ / \Gamma \omega^{* * *}$ & $-\circ / \Delta \varsigma^{* * *}$ & $-0 / 90^{* * *}$ & $-\circ / \Delta Q^{* * *}$ & $-0 / 90^{* * *}$ & $0 / 04$ & $\mathrm{pH}$ \\
\hline & 1 & $\circ / I^{* * *}$ & $\circ / V r^{* * *}$ & o/or & $-\circ / \Upsilon \Lambda^{* * *}$ & $0 / 19^{*}$ & $-0 / Y Y^{* *}$ & 0109 & TDS \\
\hline 1 & $-0 / 41^{* * *}$ & $\circ / 10$ & $-\circ / \Psi V^{* * *}$ & $-\circ / \mu_{\circ}^{* * *}$ & $-0 / 0 \wedge$ & $-\circ / \Delta \Delta^{* * *}$ & $-0 / \Upsilon \varphi^{* *}$ & $-0 / 0 V$ & $\mathrm{Q}$ \\
\hline
\end{tabular}

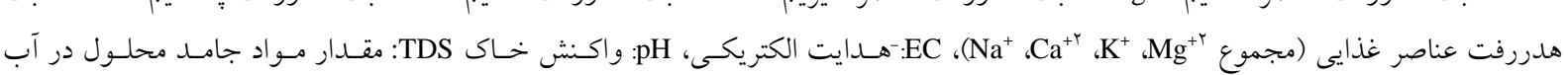
رودخانه و Q: دبى جريان. *: تفاوت معنى دار در سطح احتمال ه9 درصد، *:: تفاوت معنى دار در سطح احتمال ه9 درصد و ***: تفاوت معنى دار در سطح احتمال 99/99 درصد دودابه

يايينترين بود (ياييز)، مقدار TDS بيشترين مقدار بود. براسـاس

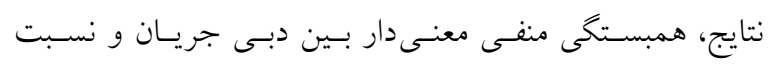
هدررفت كل عناصر غذايى (NR) مشـاهده شـــ كـه مسىتـوان

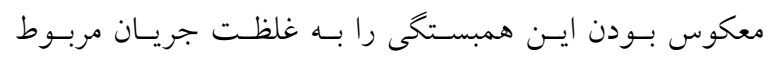
دانست. نتايج هم:جنين نشـان داد كـه همبسـتكى معنسى دار بـين
ساير شاخص هاى كيفى آب بـا اسـفاده از ضـريب همبسـتخى بيرسون (r) بررسى شد (جدول \&). نتايج نشان داد كه بين دبسى جريــان رودخانـهه و مقــدار كـل مــواد جامـــ محلـول (TDS)

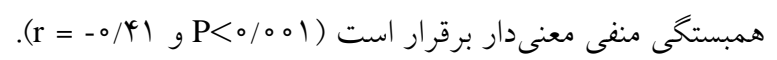
اين نتيجه نشان مىدهـد در مـاههـايى از سـال كـه دبسى جريـان 


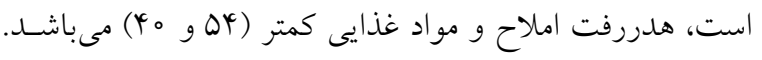

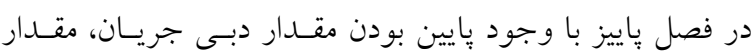

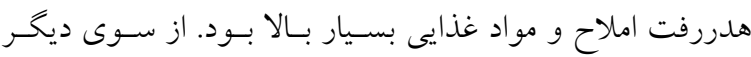

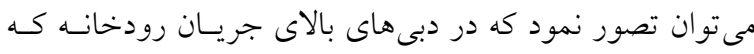

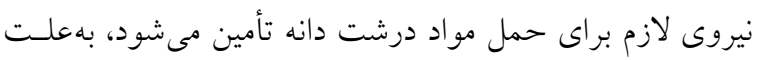

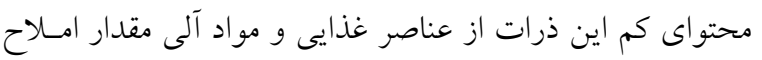
حل شده نيز كمتر مىباشد (QF).

\section{نتيجه گيرى}

اين يثزوهش نشان داد كه دبى جريـان رودخانـه داراى تغييـرات

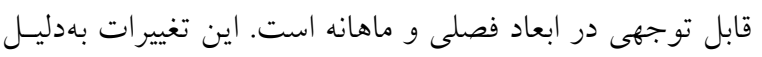

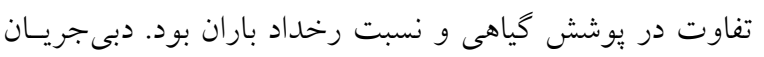

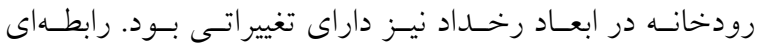

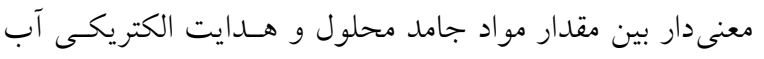

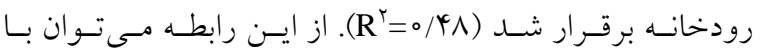

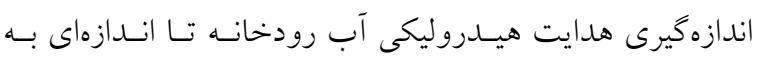

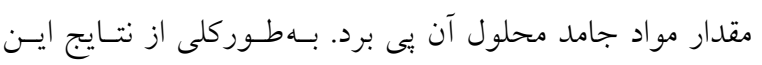

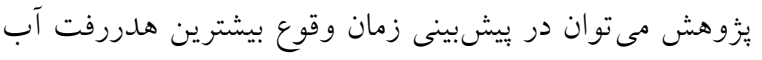

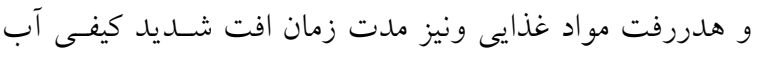

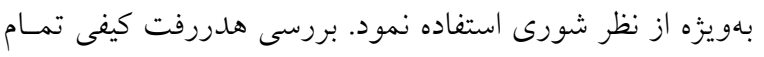

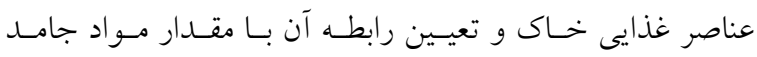

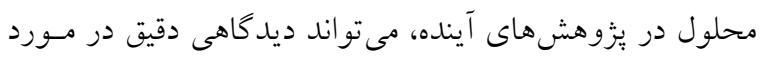
هدررفت تمام عناصر ارائه نموده و در نتيجه در برنامهريزىهاى مديريتى سودمندتر واقع كردد.

\section{سياسگزارى}

بدينوسيله از شركت سهامى آب منطقهاى زنجان كه دادههـايى

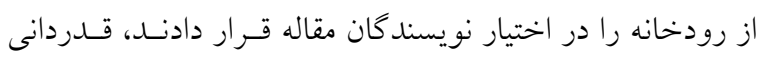

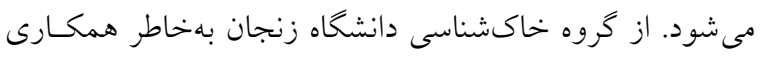

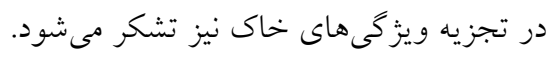

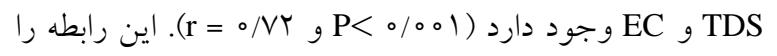
مى توان بهصورت معادله خطى زير بيان كرد: $\mathrm{TDS}=0 / 4 \wedge(\mathrm{EC})+9 \varphi / \Delta r\left(\mathrm{R}^{r}=. / 4 \wedge\right)$

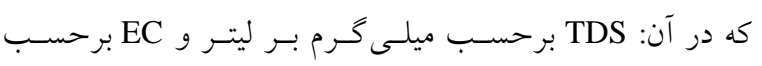

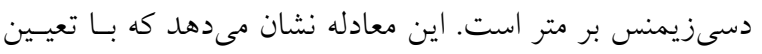

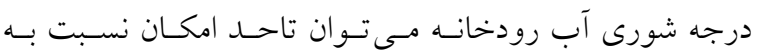

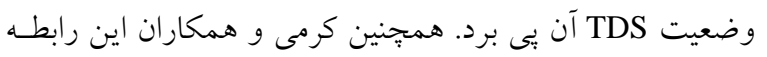

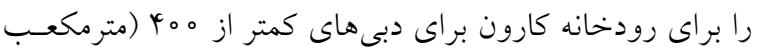

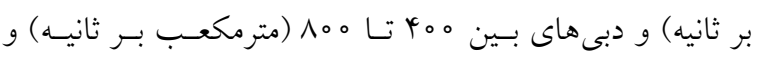

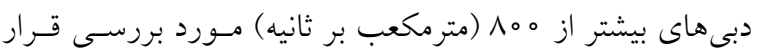

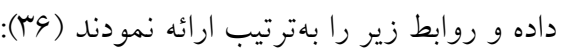
$\operatorname{TDS}=\circ / \Delta \wedge(E C)+\operatorname{vQ} / \Delta \mathrm{\Delta r}^{r}\left(\mathrm{R}^{r}=。 / \wedge \Delta\right)$

$\mathrm{TDS}=. / 9 \varphi(\mathrm{EC})-r \Delta / 9 \vee\left(\mathrm{R}^{r}=。 / 9 \varphi\right)$

TDS $=\circ / 9 \Delta(E C)-r \Lambda / \mu_{\Lambda}\left(\mathrm{R}^{r}=\circ / 9 \Lambda\right)$

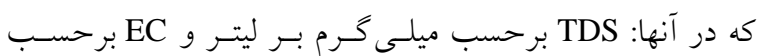
دسىزيمنس بر متر است.

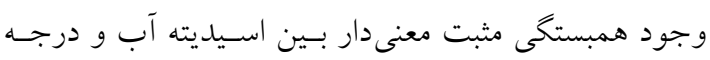

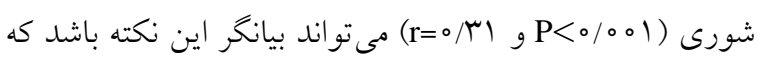

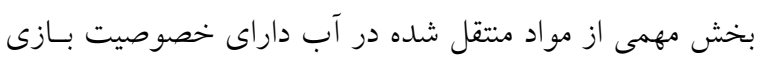

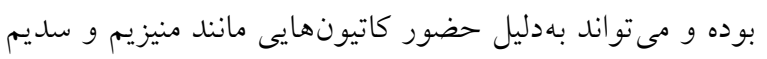

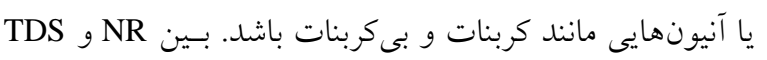

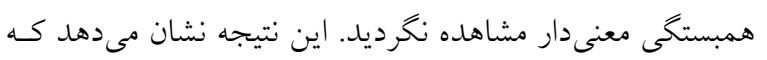

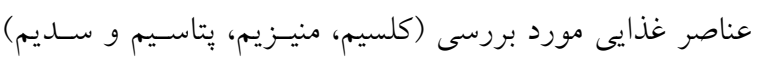
تنها بخش اندكى از كل املاح منتقله در آب رودخانه مى باشسـند.

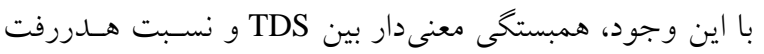

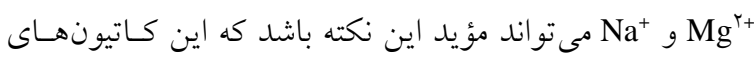

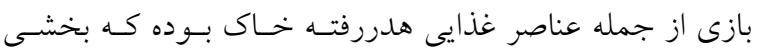

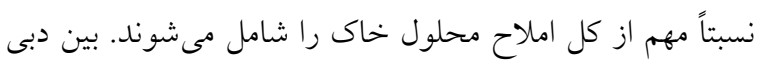

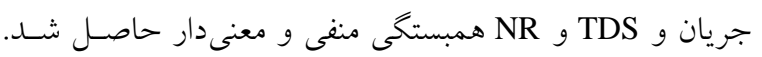

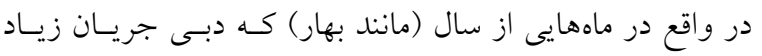


ا. احمدى كلى، ك.، ف. كيانى و م. بارانى مطلق. اجها. بررسى ميـزان هـدررفت كلسـيم و منيـزيم در رودخانـه كركـانرود اسـتان

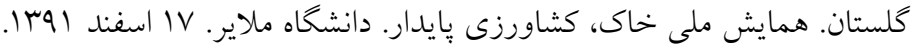

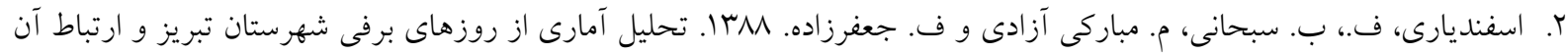

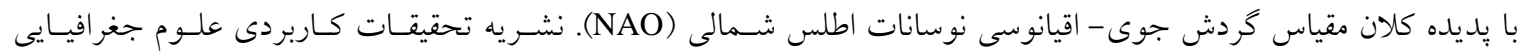
$\Lambda \mu-1 \circ r:(1 r) \mid$ 。

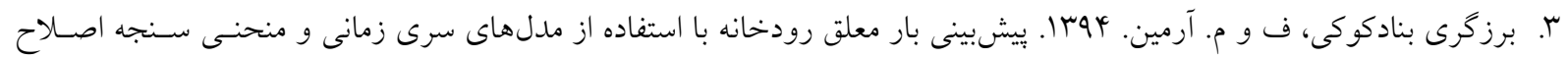

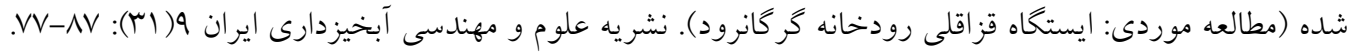

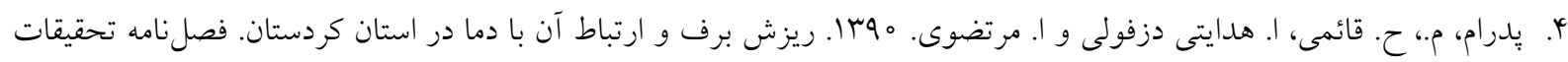
جغرافيايى ه

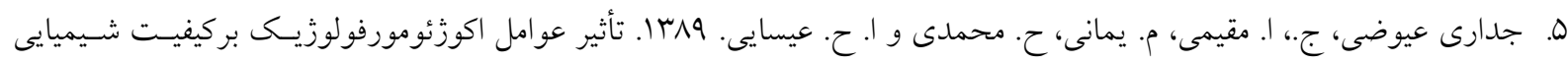

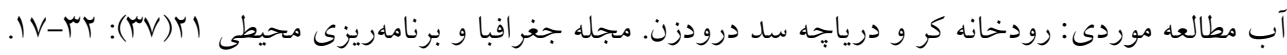

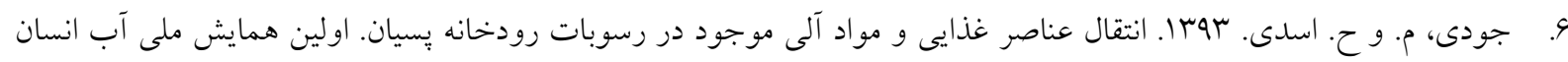
و زمين. دانشخاه اصفهان. و شهريور وهبا.

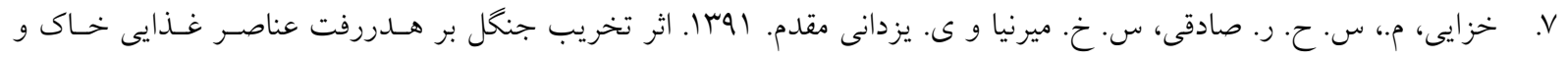

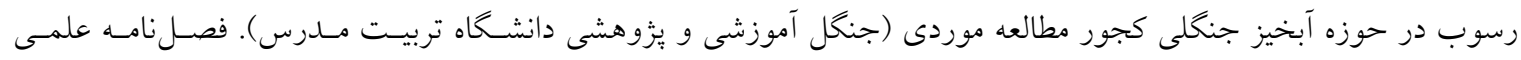

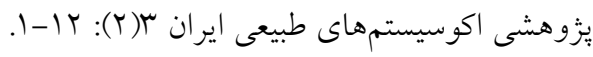

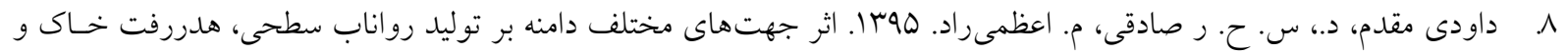

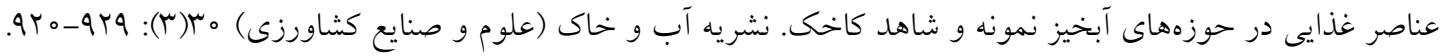

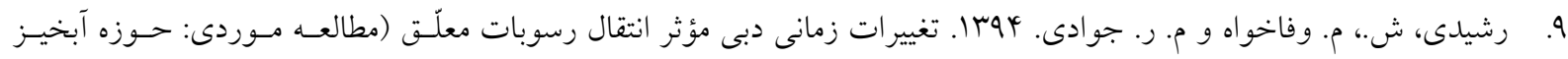

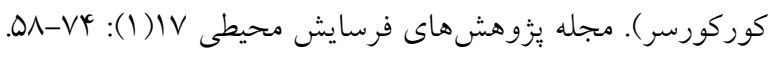

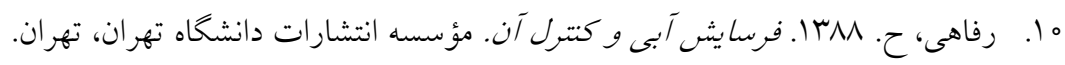

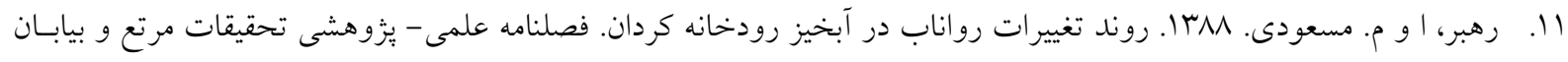
ايران

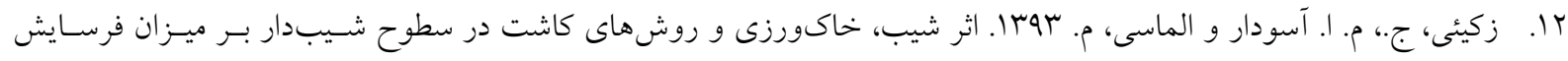

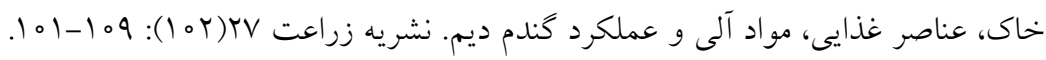

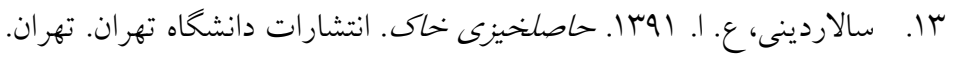

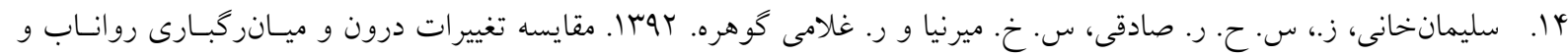

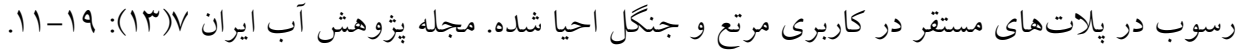

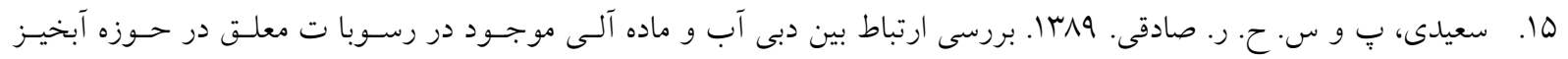

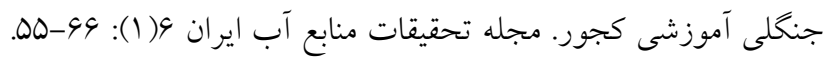

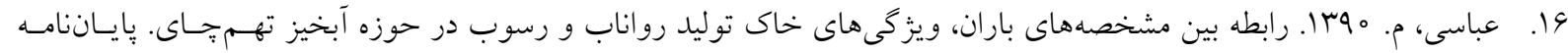




$$
\begin{aligned}
& \text { كارشناسى ارشد خاكشناسى، دانشكده كشاورزى، دانشخاه زنجان. }
\end{aligned}
$$

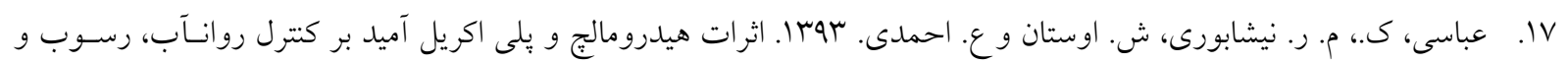

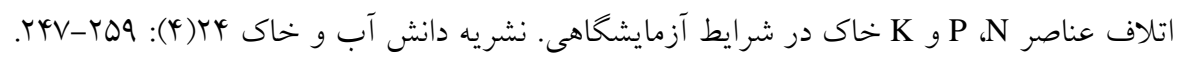

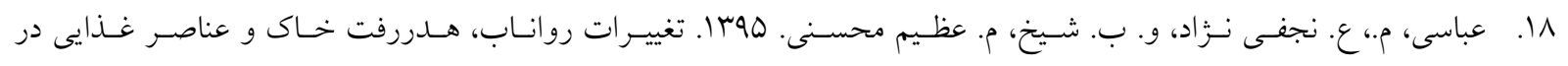

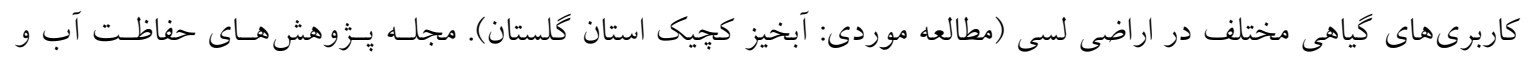

$$
\begin{aligned}
& \text { خاى سr(r): }
\end{aligned}
$$

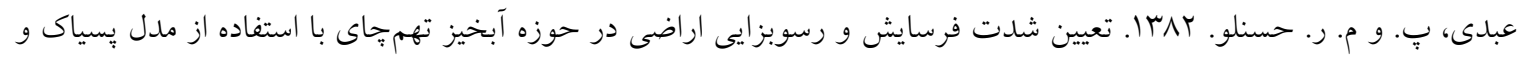

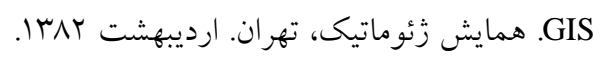

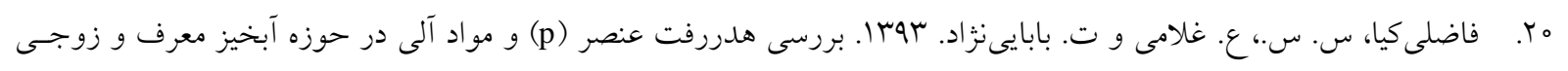

$$
\begin{aligned}
& \text { شهرستان شوش در استان خوزستان. همايش ملى ايدههاى نوين در كشاورزى يايدار. دانشخاه آزاد بروجرد. اسفند سوبا. }
\end{aligned}
$$

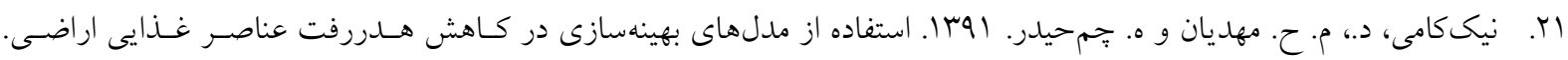

$$
\begin{aligned}
& \text { همايش ملى بيابان. دانشخاه تهر ان. خرداد الهبا. }
\end{aligned}
$$

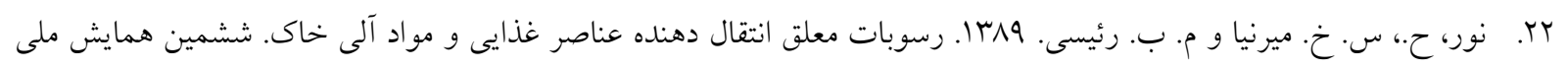

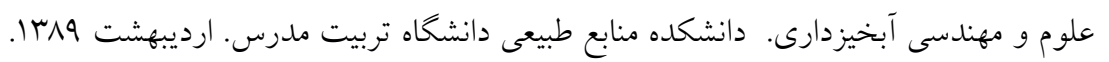

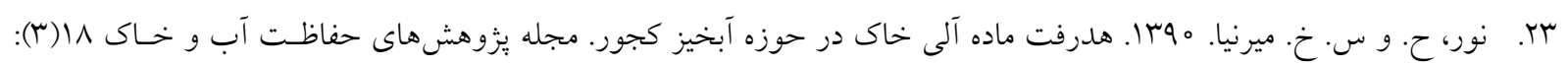

$$
\begin{aligned}
& \text {.r०V-YII }
\end{aligned}
$$

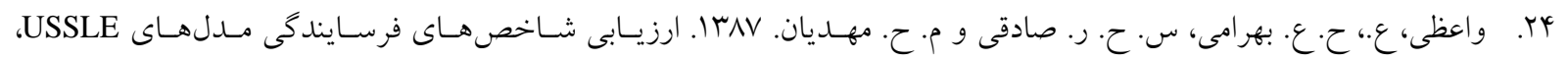

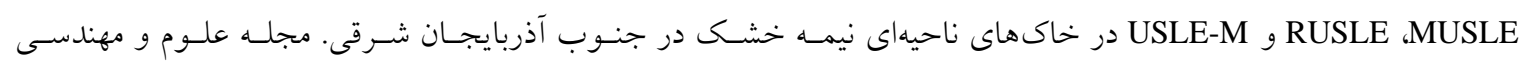

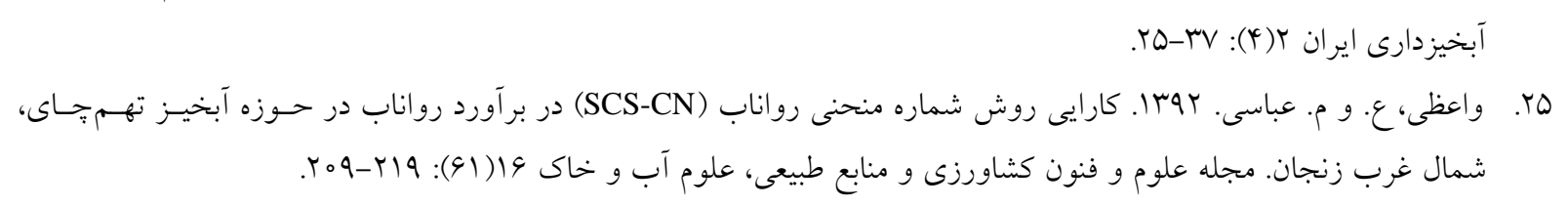

26. Ali, I. K. F. and A. U. Bahati. 2007. Soil and nutrient losses by water erosion under mono-cropping and legume inter-cropping on sloping land. Pakistan J. Agri. Res 20(3-4). 161-166.

27. American Public Health Association. 1995. Standard Methods for the Examination of Water and Wastewater. American Public Health Association, $19^{\text {th }}$ Ed. Washington, DC. P. 1467.

28. Brouder, S. M. and J. J. Volenec. 2008. Impact of climate change on crop nutrient and water use efficiencies. Physiol. Plantarum 133 (4): 705-724.

29. Brooks, K. N., P. F. Flliott and J. A. Magner. 2013. Hydrology and the Management of Watersheds. John Wiley \& Sons, Inc., New York.

30. Buchanan, T. J. and W. P. Somers. 1969. Discharge Measurements at Gaging Stations: U.S. Geological Survey Techniques of Water-Resources Investigations, Bock 3, Chapter 8, 65p. United States Department of the Interior, USGS.

31. Bunte, K., S. A. Abt, K. W. Swingle and D. A. Cenderelli. 2014. Effective discharge in rocky mountain headwater streams. J. Hydrol. 519: 2136-2147.

32. Corwin, D. L., J. D. Rhoades, J. Simunek. 2007. Leaching requirements for soil salinity control: steady-state versus transient models. Agri. Water. Manag. 90: 165-180.

33. Edwards, T. K. and G. D. Glysson. 1999. Field methods for measurement of fluvial Sediment. USGS Open-file Report 1-97 p. Available at: http://water.usgs.gov/osw/.

34. Ferreira, V., T. Panagopoulos, A. Cakula, R. Andrade and A. Arvela. 2015. Predicting soil erosion after land use changes for irrigating agriculture in a large reservoir of southern Portugal. Agric. Agricultural Sci. Procedia. 4: 4049. 
35. Jin, K. W., M. Cornelis, D. Gabriels, M. Baert. H. J. Wu, W. Schiettecatte, D. X. Cai, S. D. Neves, J. Y. Jin, R. Hartmann and G. Hofman. 2009. Residue cover and rainfall intensity effects on runoff soil organic carbon loess. Catena. 78(1): 81-86.

36. Karami, O., A. Hoshmand, S. Bazargani and M. Lamei. 2015. Evaluation of Karun river quality for irrigation in Khuzestan Province of Iran and statistical relationship of TDS and EC in classified flow rates. JCEU. 5(5): 226234.

37. Masih, I., S. Uhlenbrook and V. Smakhtin. 2011. Stream flow trends and climate linkages in the Zagros Mountains, Iran. Climate Change. 104: 317-338.

38. Maurer, E. P., J. D Rhoads, R. O. Dubayah and D. P. Lettenmaier. 2003. Evaluation of the snow covered area data product from MODIS. Hydrologic. Proc. 17(1): 59-71.

39. Men, M., Z. Yu. and H. Xu. 2008. Study on the spatial patter of rainfall erosivity based on geostatistics in Hebei province, China. Frontiers Agric. China. 2(3):281-289.

40. Mihara, M., N. Yamamoto and T. Ueno. 2005. Application of USLE for the prediction of nutrient losses in soil erosion process. Paddy Water Environ. 3: 555-559

41. Li, S., S. Gu, X. Tan and Q. Zhang, 2009. Water quality in the upper Han River. China: The impacts of land use/land cover in riparian buffer zones. J. Hazar. Materials. 195: 317-324.

42. Otero, J. D., A. Figueroe, F. A. Munoz and M. R. Pena. 2011. Loss of soil and nutrients by surface runoff in two agro-ecosystems within an Andean Paramo area. Ecol. Eng. 37 (12): 2035-2043.

43. Page, A. L., R. H. Miller and D. R. Keeney. 1982. Methods of Soil Analysis. 2 ${ }^{\text {th }}$ Ed. Part 2: Chemical and biological properties. Soil Science Society of America. Madison, Wisconnsims, USA.

44. Pearson, K. 1895. Notes on regression and inheritance in the case of two parents. Proceedings Royal Soc., London. 58(347-352): 240-242.

45. Putjaroon, W. and K. Pongewn. 1987. Amount of runoff and soil loss from various land use sampling plots in Sakolnakorn Province, Thailand. Forest Hydrology and Watershed Management. Thailand. pp: 167-198.

46. Ramos, M. C. and J. A. Martınez -Casasnovas. 2006. Nutrient losses by runoff in vine yards of the Mediterranean Alt Penedes region (NE Spain). Agric. Eco. Environ. 113(1-4): 356 -363.

47. Sadeghi, S. H. R. and H. Kheirfam. 2015. Temporal variation of bed load to suspended load ratio in Kojour River, Iran. Clean-Soil, Air, Water 43(10): 1366-1374.

48. Wang, S. B., X. X. Ma, Z. Q. Fan, W. Q. Zhang and X. Y. Qian. 2014. Impact of nutrient losses from agricultural lands on nutrient stocks in Dianshan Lake in Shanghai, China. Water Sci. Eng. 7(4): 373-383.

49. Wischmeier, W. H. and D. D. Smith. 1958. Predicting rainfall erosion losses from cropland East of the Rocky Mountains, Agricultuural Handbook 537, Washington DC, 201p.

50. Wischmeier, W. H. and D. D. Smith. 1978. Predicting Rainfall Erosion Losses. U. S. Agricultural Education and Agricultural Sciences. Handbook 537. Washington, D.C. pp: 1-62.

51. Xu, G., Y. Cheng, P. Li, Z. Li, J. Zhang and T. Wang. 2015. Effects of natural rainfall on soil and nutrient erosion on sloping cropland in a small watershed of the Dan River, China. Quaternary Int. 380- 381: 327- 333.

52. Zhang, G. H., G. B. Liu and G. L. Wang. 2010. Effects of Caranga Korshinkii Kom Cover on runoff, sediment yield and nitrogen loss. J. Sedi. Res. 25(3): 245-257.

53. Zhang, G. H., B. Liu, G. F. Wang and Y. X. Wang. 2011. Effect of vegetation cover and rainfall intensity on sediment associated Nitrogen and Phosphorus losses and particle size composition on the losses plateau. Soil Water. Cons. 66(3): 192-200.

54. Zhang, F., X. He, X. Ga. and T. Keh. 2005. Effects of erosion patterns on Nutrient Loss Following Deforestation on the Lees Plateau of Chaina. Agric. Eco. Environ. 502: 22-92. 


\title{
Temporal Variations of Stream Discharge and Nutrients Loss in the TahamChai Catchment, North-Western Iran
}

\author{
A. R. Vaezi* and Y. Mazloom Aliabadi ${ }^{1}$
}

(Received: March 14-2016; Accepted: Feb. 05-2017)

\begin{abstract}
Water loss and nutrients loss are one of the important signs of natural resource degradation in the catchments. The amount of loss of these resources is affected by several factors including the characteristics of rainfall. In this study, the data of stream discharge (Q), total dissolve solids (TDS), and total nutrient loss ratio (NR) along with rainfall characteristics were analyzed for the events from1988 to 2002 in the Tahamchai catchment, which is owned by a regional water company. Moreover, soil properties were determined by soil sampling from different points in the catchment surface. Based on the results, there was a significant correlation between $\mathrm{Q}$ of the river and rainfall height $(\mathrm{r}=0.24, \mathrm{p}<0.05)$, while its correlations with the rainfall intensity and duration were not statistically significant. On the one hand, this result was due to the inverse relationship between rainfall intensity and rainfall duration; on the other hand, due to the temporal variations in vthe egetation cover in the area, it controlled $\mathrm{Q}$ in the intensive rainfalls. The highest Q was in spring (1.68 m3 sec-1) and March (2.58 m3 sec-1). In this period, rainfall height was high and the rainfalls interval was short. Moreover, vegetation cover was weak, so it could not control surface runoff and reduce Q in the catchment. TDS and NR also significantly varied during the months and their highest values were observed in December (282.55 mg l-1) and (61.77 mg l-1), respectively. $\mathrm{Mg}^{2+}$ had the highest amount of water loss in the catchment area. A negative correlation was found between Q and TDS $(\mathrm{r}=0.41, \mathrm{p}<0.001)$ and $\mathrm{NR}(\mathrm{r}=0.31, \mathrm{p}<0.001)$. This study revealed that spring and autumn were the sensitive period for water loss and nutrient loss in the catchment, respectively. Therefore, promoting the vegetation cover in early spring and reducing improper agricultural practices (tillage and fertilization) could be substantial strategies contributing to conserving the catchment's resources.
\end{abstract}

Keywords: Watershed health, Total dissolve solids, Rainfall characteristics, Soil quality loss.

1. Dept. of Soil Sci., Faculty of Agric., Univ. of Zanjan, Zanjan, Iran.

*: Corresponding Author, Email: vaezi.alireza@gmail.com 